BYLAAG KOERS AUGUSTUS 1957.

\title{
Die Geskiedenis van die P.U. vir C.H.O. (tot Inkorporasie).
}

1. Die Beginjare: 1859-1876.

Die geskiedenis van die P.U. vir C.H.O. sit onlosmaaklik vas aan Teologiese Skool van die Gereformeerde Kerk in Suid-Afrika, want die gedagte van die stigters van die skool was nooit gerig slegs op die voorbereiding van predikante nie, maar van die begin af ook op die wetenskaplike vorming. Daarom het hulle van die begin af getrag om die opleiding te laat beantwoord aan die eise wat die beoefening van die wetenskap gestel het. Die doel was sekerlik nie die beoefening van die wetenskap ter wille van die wetenskap self nie, maar die beoefening van die wetenskap sodat dit hulpdiens kan verrig vir die verhewe doel van die verkondiging van die Woord van God aan die mens.

Die totstandkoming van die Gereformeerde Kerk in Suid-Afrika in 1859 het dadelik die groot vraagstuk van voorsiening van predikante aan die orde gestel. Die kerk was aanvanklik baie klein en die lidmate was verspreid oor 'n paar afsonderlike state, sodat die oppervlakte wat bedien moes word, enorm groot was. Tog het die stigters van die kerk nie die ö̈ gesluit vir die probleme nie, want hulle het dit bespreek en planne beraam om in die behoeftes te voorsien.

Predikante was dringend nodig en die groot vraag was waar om hulle vanda:an te kry. Die moontlikheid het bestaan om vanuit Nederland geholpe te raak en dit sou sekerlik die maklikste uitweg gewees ket. Aanvanklik is ook in dié rigting gedink, want kort na die stigting van die kerk is daar onder leiding van ds. Postma beroepe uitgebring, waarvan een opgevolg is nl. ds. Beyer, wat na sy aankoms alhier predikant van Reddersburg geword het. Hierdie weg het hulle egter nie blywend bewandel nie.

In 1862 het die eerste Algemene Sinode van die kerk vergader te Reddersburg en daar sou o.a. ook aandag geskenk word aan die vraagstuk van die opleiding van predikante. In die notule van die vergadering staan hieroor die volgende (art. 22): „Werd gesproken over het groote nut der opleiding, tot bekwaammaking van aankomende Leeraaren in Zuid-Afrika en zoo werd een geschiedkundig overzigt, 
door den Voorzitter daarover gegeven volgens het $\mathrm{O}$. en $\mathrm{N}$. Testament, alsmede uit de latere Kerkgeschiedenis; temeer doordien reeds sommige Kerkeraden hun groot verlangen daarover hadden te kennen gegeven;-werd met algemeene stemmen besloten, om de behandeling dezer groote en belangrijke zaak, tot de volgende Sijnode te verdagen: maar dat men voorloopig zal beginnen te kollekteren, in elke Gemeente zoo mogelijk om de drie maanden en wel in iedere Gemeente, naar hare beste gelegenheid, en op de e.k. Sijnode zal verslag worden gegeven van de ingekomen gelden."

Die sinode het nie die stap in die onsekere gewaag nie, maar opdrag gegee dat daar intussen gekollekteer moes word, sodat die volgende sinode meer sekerheid kon hê wanneer die saak weer bespreek sou word. Hoewel bogenoemde besluit nog nie die oprigting van 'n skool behels nie, is dit tog feitelik in beginsel aanvaar. Die tweede sinode het die volgende paar vergader in Rustenburg, en uit die acta blyk die volgende: In art. 13 staan genotuleer dat uit die Kaap Kolonie ongeveer $£ 40$ ingesamel was met die vermelding dat daar meer sou ingekom het „maar de langdurige droogte in het verleeden jaar, heeft hiertoe veel nadeel toegebragt"; uit die S.A. Republiek $£ 22.6 .3$ wat deur ds. Postma ingesamel is en dan staan daarby ,en maakt de vergadering ook opmerkzaam op de beroerten van dit land, anders zou ook hier zeker meer gekollekteerd zijn"; die bedrag wat dus ingesamel was het gestaan op E62.6.3. Dit was sekerlik nie bemoedigend nie, maar die sinode is nie hierdeur afgeskrik sodat van die saak afgestap is nie, want die hele aangeleentheid van die opleiding van predikante is deeglik onder behandeling geneem en in die notule staan dat oor die opleiding ,ernstig en veel gesproken is en tevens met groote belangstelling". By die geleentheid is ook ' $n$ brief van ds. Postma aan die sinode hieroor voorgelees waaruit ons die volgende aanhaal: „Dewijl ik de Gemeenten, in deze landen, niet alleen wensch te dienen zoo veel ik kan in mijn leven, maar ook na mijne verscheiden, zoo raad ik de Synode ernstig aan te zorgen, voor eene Kerkelijke Opleiding van persoonen tot de $\mathrm{H}$. bediening, en zich in dezen, niet afhankelijk te gevoelen, nocht te maken van de wereldsche Overheid, tot het inrigten van die gelegenheden, en nog veel minder zich afhankelijk te maken, van vreemden invloed."

Nadat die skrywer dan uit die H. Skrif op sekere voorbeelde gewys het, gaan hy verder ,daarom raad ik dat de Kerk, indien mogelijk, zulk eene inrigting daarstelle, naar haar vermogen, waar jongelingen of 
mannen, van bekwamen aanleg en beproefde christelijke gebindheid, de nodige kundighede kunnen verkijgen onder Gods genadigen invloed en leiding des H. Geestes, tot het ambt van Herder en Leraar." ")

In hierdie woorde kan ons die heilige erns waarmee ds. Postma die saak benader het, lees. Dit is nie onverskilligheid wat daaruit straal nie, maar die erns van die saak wat hom genoop het om só te pleit vir die oprigting van 'n skool waarin die aanstaande leraars ,de nodige kundigheden kunnen verkrijgen . . .". Niemand het beter geweet as hy hoeveel opofferinge da:armee gepaard sou gaan, maar hy het ook geweet watter gevare daaraan verbonde was as die kerk vir die opleiding van sy aanstaande bedienaars van die Woord na die Owerheid moes kyk. Daarom het hy so gepleit terwyl hy geweet het dat die resultaat van die kollekteerwerk so uiters moedbenemend was.

Maar die skrywer van die brief was nie 'n idealis sonder meer nie wat eenvoudig sy oë gesluit het vir alle feite en gesê het: Dit moet. Hy sluit sy brief af met die volgende gedagte: „En-zoo de Synode nog geene mogelijkheid ziet, om dit als Kerk daar te stellen, dat dan ieder Leraar zijn best doe, om hierin bezig te zijn, zoo veel hem mogelijk is. . ten einde de Kerk van af heden haar eigen element beware en bevordere, naar de genade Gods die haar is en worde verleend door Woord en Geest ...":)

Die saak is baie ernstig en langdurig bespreek en eindelik is besluit: „Dat de Synode, nu nog geene stappen kan doen om iets bepaald te ondernemen, hoewel allen doordrongen zijn, van het groot belang, om eene eigene Opleiding te bezitten; daarom besluit de Synode, om nog maar eerst voort te gaan, met kollekteren, zoo mogelijk om de drie maanden, in elke gemeente, en-neemt op zich om de gemeenten steeds meer het belangrijke van eene zoodanige inrigting, bekend te maken" ")

Die besluit het verder ingehou dat die leraars gevra sou word om wanneer daar persone hulle vir opleiding aangemeld het, hulle bes te doen om die opleiding te verskaf en hulle dan op die Algemene Sinode sou laat eirsamineer. Die eienaars het hulle hiertoe bereid verklaar.

Ons stel dus vas dat die kerk in 1863 nog nie in staat was om sodanige opleiding te voorsien nie, maar van die saak is nie afgestap nie, want dit moes gedurig onder die aandag van die gemeentes gebring word, sowel deur daarvoor te kollekteer as deur op die noodsaaklikheid van so'n Skool te wys. 
Dat die sinode egter nie die hele saak van opleiding van predikante in die midde gelaat het nie, blyk uit die laaste deel van die besluit. ${ }^{\text {s) }}$ In hierdie versoek wat gerig was aan die predikante, moet ons inderdaad die eerste begin van die toekomstige opleiding sien, want as gevolg daarvan kon persone wat hulle bereidwillig verklaar het vir die opleiding, toegerus word en deur die sinode ooreenkomstig artt. 4 en 5 van die Kerkorde van Dordrecht 1618-19 ondersoek en beroepbaar gestel word. Dit het ook inderdaad vrug afgewerp want reeds op die sinode wat in 1866 te Reddersburg gehou is, het vier persone hulle aangemeld vir ondersoek met die oog op toelating tot die bediening van Woord en Sakramente. Twee van hulle is inderdaad toegelaat." )

Op die sinode is die saak van die oprigting van 'n eie Teologiese Skool weer ter sprake gebring, maar dit is afgestem en die bestaande toestand is gehandhaaf. ") Daar sou egter 'n klein verandering in die bestaande toestand kom en dit deurdat die sinode besluit het om 'n sinodiale kommissie te benoem wat sou bestaan uit die diensdoende predikant met twee ouderlinge uit elke staat om ingeval studente hulle intussen mag aanmeld vir eksamen, hulle te ondersoek in naam van die sinode en ook toe te laat as die nodige bekwaamheid gevind mag word. ${ }^{8}$ ) As gevolg van hierdie opdrag is daar voor die volgende sinode nog 'n kandidaat toegelaat tot die bediening, t.w. J. L. Cachet.

In 1869 het die vierde Algemene Sinode vergader in Potchefstroom en op hierdie vergadering sou die belangrike besluit geneem word insake die oprigting van 'n Teologiese Skool.

Teneinde die besluit van hierdie vergadering in die regte lig te besien en sodoende die geloofsmoed van die stigters reg te kan waardeer, ontleen ons die volgende gegewens aangaande die kerk aan die Acta van gemelde sinode: Op die sinode was daar verteenwoordigers van vier uit die vyf gemeentes van Transvaal; van al vier gemeentes van die O.V.S. en van al ses die gemeentes van die Kaap Kolonie. Volgens die statistieke van die gemeentes wat in die Acta opgeneem is, blyk dat daar toe in Transvaal 1397 belydende lidmate was; in die Vryst:aat 985 en in die Kaap Kolonie 1980, dus 'n totaal van 4,362 belydende lede, wat verspreid was oor drie state en georganiseer in 15 gemeentes. Daar was toe vier diensdoende predikante, want ds. Beyer het intussen teruggekeer na Nederland. Verder sou op die sinode weer 'n drietal kandidate toegelaat word. ${ }^{\text {) }}$ ) 
Toe die sinode weer aandag gegee het aan die groot saak van opleiding van aanstaande bedienaars van die Woord, het dit geblyk dat nie net Burgersdorp nie, maar ook ander gemeentes voorgestel het dat 'n Teologiese Skool opgerig moes word. Nadat ds. Postma sekere gegewens verstrek het aangaande die oprigting van 'n skool deur die Christelijk Afgescheiden Gereformeerde Kerk in Nederland in 1854, is aan die verskillende afgevaardigdes geleentheid gegee om mee te deel wat die gemeentes respektiewelik jaarliks kon bydra. ${ }^{10}$ )

Die resultaat hiervan was soos volg:

$\begin{array}{lr}\text { Transvaal } & \mathfrak{6 8} \\ \text { Vrystaat } & 43 \\ \text { Kolonie } & 300\end{array}$

$\mathfrak{1 4 1 1}$

Hierna is genotuleer: „De Synode besluit nu dat met 's Heeren hulp de Theologische School zal opgerigt worden." ")

Toe is gespreek oor die traktement van 'n tweede leraar en met die oog op die beloofde bydrae besluit die sinode om dit te stel op $£ 400$ en vrye woning en dat die volgende sinode hierop sal terugkom indien nodig om dit te hersien. ${ }^{12}$ )

Toe pas het die sinode aandag geskenk aan die volgende voorstel van die gemeente Burgersdorp:

1. Dat de School opgerigt worde te Burgersdorp;

2. dat de Synode slechts uitbreiding geve aan hunnen staande inrigting die de kerkeraad zelf onder leiding van hunnen leeraar daargesteld heeft, en dat dan de gemeente Burgersdorp en de andere gemeentes der Kaap Kolonie een gebouw tot 2de Pastorie, reeds gekocht, als vrij en onbelemmerd eigendom aan de Gereformeerde Kerk van Zuid-Afrika ten geschenke zullen geven;

3. de gemeente Burgersdorp zal instaan voor pastorie en onderhoud van éénen Leraar, en voor den tweeden bijdragen gelijk de andere gemeenten, tevens zal zij den aanwezige School ameublement aan de Theologische School present geven." ${ }^{13}$ )

Om hierdie voorstel van Burgersdorp reg te verstaan en te waardeer is dit nodig dat ons kortliks sal let op wat daaraan voorafgegaan het.

In 1860 het die gemeente Burgersdorp totstandgekom en reeds op 11 Feb. 1862 het die eerw. kerkraad onder voorsitterskap van die kon- 
sulent, ds. Postma, ernstig gehandel oor die opleiding van aanstaande predikante en toe is besluit ,onder inwachting van de goedkeuring van onze e.k. Synodale verg. te zien of men niet zoude kunnen daarstellen een „School ter opleiding van bedienaren des goddelijken Woords onder de leiding van twee Leeraren aan eene plaats, die dan te gelijk ook die gemeente konnen bedienen."

Hierdie voorstel is deur sowel die kerkraad as die gemeente geesdriftig ondersteun. En die kerkraad het, toe dit rugbaar geword het, selfs 'n erf present gekry vir daardie doel van 'n sekere I. J. Herman wat nie lidmaat van die gemeente was nie. ${ }^{14}$ )

Toe die saak op die volgende Sinode behandel is, is egter besluit om maar te volhard op die weg dat die twee predikante afsonderlik die kandidate moes onderrig. ${ }^{1+} \mathrm{a}$ ).

Op 25 Junie 1864 het die kerkraad van Burgersdorp onder voorsitterskap van ds. Beyer vergader, maar op uitnodiging was ds. Postma ook teenwoordig. By dié geleentheid is weer gehandel oor die opleiding van predikante en toe is besluit om maar weereens te trag om langs die weg van art. 8 Kerkorde die kerk van predikante te voorsien en dat inmiddels die leraars maar moet voortgaan met hulle opleidingswerk. ${ }^{15}$ )

'n Paar weke later, 15 Junie 1864, is weer aandag geskenk aan die saak en toe is op advies van ds. Postma besluit om 'n Algemene Vergadering van al die gemeentes van die Kaap Kolonie te hou om die saak van opleiding te bespreek. $\left.{ }^{1 "}\right)$ Hierdie vergadering is gehou te Burgersdorp op 20 Aug. 1864 en bygewoon deur afgevaardigdes van al die gemeentes van die Kaap Kolonie. Nog voor die vergadering is ds. Postma al deur die kerkraad van Burgersdorp saam met van die ander kerkrade beroep tot professor in die Teologie; maar hy sou later sy antwoord daarop bekendmaak. ${ }^{16} \mathrm{a}$ )

$\mathrm{Na}$ die saak van die opleiding van predikante behoorlik bespreek is op die Algemene Vergadering, is besluit:

1. Dat de opleiding worde opgedragen aan de twee leeraren die nu de Kerk bedienen en dus dat de Weleerw. Heer Beyer aan Postma worde toegevoegd.

2. En dat, indien het mogelijk is, de zitting der Synode worde vervroegd ten einde die belangrijke zaak te bevorderen." ${ }^{17}$ )

Op die beroep het ds. Postma geantwoord dat die saak van opleiding deur die hele kerk behandel moes word en gevolglik kon hy die roeping nie opvolg nie." 
Intussen het die gemeente Burgersdorp verskeie beroepe uitgebring op predikante in Nederland sonder enige gevolg. In 1866 het die gemeente toe vir ds. Postma beroep en in Mei van daardie jaar is ds. Postma aldaar bevestig as predikant. Onder sy leiding het Burgersdorp sake in gereedheid gebring om op die e.v. sinode wat in 1869 sou vergader, die voorstel tot oprigting van 'n Teologiese Skool te doen. Dit is hierdie voorstel wat ons hierbo aangehaal het. Vooraf is ook waarborglyste deur die gemeentes geteken, sodat op die sinode die bedrag van $\mathbf{1 4 1 1}$ per jaar gewaarborg kon word.

$\mathrm{Na}$ hierdie uiters belangrike besluit insake die oprigting van ' $n$ skool waar die aanstaande predikante opgelei kon word, het die sinode verder nog aandag geskenk aan die uitvoering daarvan. Deur die aanname van die voorstel van Burgersdorp, sou die predikant van die gemeente dus een van die leraars wees. Ds. Postma het hom dus tydens die bespreking van hierdie deel van die voorstel verwyder uit die sinode, en toe dit aan hom meegedeel is, het hy nie dadelik geantwoord nie. Later het hy skriftelik geantwoord dat hy die roeping slegs met huiwering aanvaar omdat $h \bar{y}$ besef dat sy wetenskaplike toerusting nie voldoende was nie, maar dat hy nogtans die taak hoop te aanvaar deur Gods krag. ${ }^{19}$ )

Wat in hierdie brief opval is die klem wat ds. Postma laat val op die wetenskaplike toerusting, en gaandeweg word ook hierdie eis ingeskerp by die studente, sowel as by die persone wat as leerkragte aangestel moes word.

As tweede leraar is deur die sinode benoem ds. J. Lion Cachet

Hoewel dit tot sover meesal benadruk is dat die kerk 'n Skool moes hê waar die aanstaande predikante opgelei kon word, is dit opmerklik dat die sinode ' $n$ besluit geneem het waaruit blyk dat daar ook ander behoeftes gevoel is in hierdie verband. Hiervan is die volgende besluit 'n duidelike bewys: „De Synode besluit, dat de kweekschool te Burgersdorp zoo ingerigt worde, dat er niet alleen predikante aangevormd worden, maar ook jongelingen zich kunnen bekwamen tot onderwijzers der jeugd, ja ook jongelieden, zonder een bestemd doel te hebben, gelegenheid gegeven wordt, naar hunne vatbaarheid gebruik van de School te maken, allen anderworpen aan de regulatiën der School". ${ }^{20}$ )

Vir ons doel is dit ' $n$ besonder belangrike besluit hierdie, omdat dit die bewys lewer dat die stigters van die Skool veel meer in gedagte gehad het as 'n gewone kweekskool wat slegs toeganklik sou wees vir per- 
sone wat predikant wou word. Twee onder groepe van jong manne word uitdruklik genoem, nl. die wat onderwyser wou word en verder die wat sonder 'n besondere doel daarheen wou gaan slegs vir 'n algemene opleiding en vorming. In hierdie besluit van die sinode moet ons inderdaad die begin sien van die toekomstige Universiteit wat daaruit gegroei het.

Op Maandag, 29 November, 1869, is die Skool plegtiglik geopen met twee dosente en vyf studente. Die vakverdeling tussen die twee dosente was soos volg:

Ds. Postma: Latyn, Grieks, Hebreeus, Logika en Retorika, Bybelse Geskiedenis, Godgeleerdheid, Pastoraal, Geskiedenis en die inhoud van die Formuliere van Enigheid, Liturgiese geskrifte en Kerkregering.

Ds. Cachet: Hollandse taal en styl, Latyn (jong klasse), Grieks (beginners), Hebreeus (beginners), Matesis, Fisika en Metafisika, Oorsig van die Algemene Geskiedenis, Griekse en Romeinse oudhede, Kerkgeskiedenis, Exegetiek. ${ }^{24}$ )

As ons hierdie vakverdeling noukeurig nagaan, merk ons dadelik die realisering op van wat in die sinodebesluit vervat was, $\mathrm{nl}$. dat die opleiding nie slegs 'n enge toerusting sou wees om te kan preek nie, maar ' $n$ poging om dit so breed as moontlik te mak en die beginselleiding dus so omvattend as maar kan. Afgesien van die onderrig in die verskillende tale en geskiedenis is ook Logika en Metafisika en Retorika, Matesis en Fisika tesame met die hele omvattende studie van Teologie ingesluit. Hier het die voorbereiding dus inderdaad die eerste voetstap gesit op die weg van wetenskaplike toerusting in die toekoms. Dit was weliswaar nog die dag van kleine dinge, maar daar is nie met minagting daarop neergesien nie, sodat die funderingswerk heg en stewig gelê is.

Die sinode van 1869 het nog 'n uiters belangrike besluit geneem: „Die Synode besluit dat de Kweekschool te Burgersdorp zoo ingerigt worde, dat er niet alleen predikante aangevormd worden, maar ook jongelingen zich kunnen bekwamen tot onderwijzers der jeugd, ja dat ook jongelieden, zonder een bestemd doel te hebben, gelegenheid gegeven wordt, naar hunne vatbaarheid gebruik van de school te maken, allen onderworpen aan de regulatiën der school." "'a).

Naas die stigtingsbesluit is dit beslis die belangrikste daad van die sinode, want dit sou met reg die geboorte-uur van die latere literariese departement genoem kan word, wat op sy beurt weer die begin was van 
die huidige Potchefstroomse Universiteit vir Christelike Hoër Onderwys. Met daardie besluit het onse vaders getoon dat hulle nie net besorgd was oor die vorming van toekomstige predikante wat die gemeentes kon bedien nie, maar ook gedink het aan die toekomstige opvoeders van die jeug en selfs aan die manne wat gevorm moes word vir hulle tixak in die algemeen, ook as hulle sou moes optree as leiers in hulle omgewing. Die besluit betrek inderdaad diegene wat toerusting verlang het vir hulle taak op kerklike sowel as maatskaplike terrein.

Die uitvoering van hierdie belangrike besluite van die sinode was opgedra aan die Kuratore wat die belange van die skool sou moes behartig. In die notule van die Kuratorevergadering staan dit dat aan die Owerheid van die Kaap Kolonie behoorlik kennis gegee is van die stigting van die Skool te Burgersdorp. ${ }^{2}$ ) Verder dat aan die voorsitter van die Kuratore, ds. N. J. R. Swart, opdrag gegee is om 'n verslag van die stigting van die skool te stuur aan „De Bazuin", 'n blad wat deur die Teologiese Skool van die Christelik Afgeskeie Gereformeerde Kerk in Nederland uitgegee is. ${ }^{23}$ )

Die Kuratore het ook gereël dat die Rektoraat van die Skool jaarliks sou wissel.

Gedurende die beginjare het sake normaalweg verloop en hoewel die getalle gering gebly het, het die dosente hulle werk nougeset verrig. In 1875 het dosent Cachet 'n beroep aangeneem na die gemeente Philipstown, sodat op 'n buitengewone kuratorevergadering, gehou op 30 Augustus 1875, aan hom eervolle ontslag verleen is. Daar is nie direk 'n opvolger aangewys nie, want die kuratore het tydelike voorsiening gemaak om sy werk te laat voortgaan. Blykbaar sou die saak v.an 'n opvolger vir ds. Cachet op die volgende sinode bespreek word, maar die notule maak daar geen melding van nie.

II. Die jare 1876 tot 1903.

Reeds op die sinode van 1873 het sekere veranderinge by die skool aandag geniet. Ds. Postma het bv. in 'n brief aan die sinode sy bereidwilligheid te kenne gegee om sy betrekking as eerste dosent neer te lê, sodat die sinode dan 'n bekwamer man as hy kon aanwys. Hy het vooraf gewys daarop dat hy homself nie wetenskaplik genoeg gevorm ag vir die groot taak nie. ${ }^{23} \mathrm{a}$ )

Die sinode het die brief behandel maar wou die versoek nie bewillig nie, terwyl aan die ander kant aan ds. Postma die versekering gegee is 
dat hy die vertroue van die vergadering wegdra en dat hy maar moes aangaan met sy werk..$^{24}$ )

Afgesien hiervan is die saak van meer doeltreffende onderwys aan die Skool ook op die sinode gebring en gevolglik is aan die Kuratore opgedra om in oorleg met die dosente te oorweeg ,of men niet vervolgens het eksamen der studente zal splitsen in een literarisch en eindeksamen om de e.k. Synode te dienen met advies." ${ }^{25}$ )

Hierdie opdrag sou aanleiding wees dat die sinode van 1876 'n uiters belangrike reorganisasiebesluit sou neem ten opsigte van die Teologiese Skool.

Die Kuratore het dan ook in verband hiermee op hulle vergadering van 1 April 1876 te Reddersburg besluit: „De eerw. Synode te adviseren het eksamen te splitsen in een literarisch en eindeksamen." ${ }^{20}$ )

Op hierdie sinode het ds. Postma weer gevra dat die sinode hom as dosent moes onthef van sy taak om beter voorsiening te maak. Toe die sinode hierdie versoek nie wou bewillig nie, het ds. Postma die vergadering meegedeel dat hy sonder ontheffing van die doseertaak nie kon meewerk aan die reorganisasieplanne vervat in die beskrywingspunt van Burgersdorp nie en dat dit hom temeer sou spyt aangesien dit eintlik sy beskrywingspunt was. Die sinode het hierop die versoek bewillig en die eerste dosent van sy opdrag onthef, sodat hy daarna kon optree as predikant van Burgersdorp en deelneem aan die bespreking van die volgende beskrywingspunt:

1) „Dat de Synode twee professoren aanstelle voor de Theologische School, geheel vrij van kerkelijken dienste behalve misschien eenig aandeel in de prediking ten belange ook der studenten.

2) De gemeente van Burgersdorp geniete weer haren herder en leeraar, zonder dat die leeraar eenige bijzondere verplichting aan de school heeft."

By hierdie beskrywingspunt het ds. Postma as sy wens gevoeg: „Dat de Synode er toe mocht besluiten om aan de Theologische School te verbinden eene voorbereidende School, met een gequalificeerden onderwijzer aan het hoofd, waar tegelijkertijd personen voor onderwijzers kunnen opgeleid worden."

Saam met die punte het die voorsitter van die sinode ook nog die volgende punt uit die Kuratoreverslag laat behandel: „Met het oog op de bestaande vacature, beveelt de Collegie der curatoren de school ern- 
stig aan de belangstelling der Synode aan, mocht het zijn tot verdere versterking en uitbreiding derzelve." "7)

$\mathrm{Na}$ breedvoerige bespreking is besluit om die gemeente Burgersdorp van hede af te ontslaan van die besondere betrekking waarin dit vanaf 1869 gestaan het tot die Skool, met 'n woord van besondere dank vir die groothartige opoffering in verband met hierdie saak. Verder het die sinode daartoe oorgegaan om lerare aan te wys wat voltyds verbonde sou weer aan die Skool. ${ }^{28}$ ) In aansluiting by hierdie beslissing is toe die uiters belangrike voorstel ingedien wat ons hier gedeeltelik aanhaal:

„De Synode overgaande tot het beroepen van de leeraren aan de Theologische School, besluit:

1e Heden te beroepen een van de welvertrouwde predikanten onzer Kerk, zoowel in Nederland als in Zuid-Afrika, tot professor theologicus, met een salaris van $£ 500$ per jaar en vrije woning in de pastorie der kerk;

2e Daarna tot het beroepen van een professor litterarum, die niet een minder graad moet bezitten dan B.A. hetzij dan al of niet predikant zijnde, met een salaris van $£ 400$ per jaar, zonder vrije woning.

3e Eindelijk tot het beroepen van eenen gequalificeerden onderwijzer

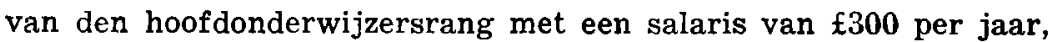
zonder vrije woning." ${ }^{2 \prime}$ )

Hierdie voorstel is puntsgewyse behandel en punte 1 en 2 is aanviaar deur die sinode, maar punt 3 is onder omstandighede afgestem. Verder is ook nog besluit dat die kuratore opdrag ontvang om die professor litterarum aan te stel.

Met die deurvoering van hierdie reorganisasieplan was nie net die Teologiese studie op ' $n$ vaster voet geplaas nie, maar kon ook beter aandag gegee word aan die propedeutiese studie. Die daarstelling van die Literariese Departement was dus die wesenlike begin van die inrigting wat later daaruit sou groei tot 'n selfstandige universiteit.

Op die sinode is ook nog aandag gegee aan die splitsing van die eksamen in 'n Voorbereidende en Eindeksamen soos ons reeds tevore aangedui het. Hierdie aanbeveling van die Kuratore is deur die sinode goedgekeur. ${ }^{\text {iw }}$ )

As gevolg van hierdie besluit tesame met die reorganisasie wat deurgevoer is, het ' $n$ herreëling van die vakke waarin onderrig verskaf sou word, nodig geword en dit is soos volg deur die eerw. sinode goedgekeur. Omdat hierdie besluit vir ons doel van groot belang is, haal ons 
hier daardie deel aan wat van toepassingn was op die Literariese Departement:

„De Synode verlangt dat de Curatoren zorgen, dat, zooveel als mogelijk is, in de Theologische School geleerd worden de navolgende vakken:

1. De Hollandsche taal, stijl en letterkunde, en evenzoo de Engelsche taal en letterkunde;

2. Latijn, Grieksch, Hebreeuwsch en bybelsch-Chaldeeuwsch;

3. De Algemene Geschiedenis en ook de Geographie en Mythologie voor zooverre die tot de geschiedenis vereischt worden;

4. Natuurkunde;

5. De Logica en Metaphysica.

En wel dat de studenten in bovengenoemde vakken zóó onderwezen worden, dat zij zich kunnen bekwamen om zich tot het examen van B.A. te kunnen aanbieden, zulks verkiezende." "1)

By nadere ontleding van hierdie leervakke merk ons op dat dit wel nie ingrypend verskil van die reëling wat met die opening van die Skool ingevoer was nie, maar dat daar naas die ou tale ook meer aandag geskenk sou word aan die moderne tale soos Nederlands en Engels. En dat die byvoeging dat die onderrig in die vakke sodanig moes wees, dat die kandidate, desverkiesend, hulle kon aanmeld vir die eksamen vir die B.A.-graad lewer vir ons 'n duidelike bewys dat die sinode nie tevrede was met die ou toestand nie, maar vorentoe gebeur het en die toerusting van die jongmanne so deeglik as moontlik wou makk.

Vir die verhoging van die peil van die onderwys was daar ook nog 'n ander faktor waarmee die sinode rekening moes hou en wat ook inderdaad aandag geniet het, nl. die instelling van 'n Admissie-eksamen voor die toelating tot die Skool.

Vodgens die skema wat die Kuratore uitgewerk het vir die Admissie-eksamen, het dit uit die volgende vakke bestaan:

1. Grondbeginsels van die Hollandse taal;

2. beginsels van die rekenkunde, stelkuns en die meetkuns;

3. Algemene Geskiedenis en geskiedenis van Suid-Afrika;

4. Bybelse geskiedenis en 'n oorsig van die Kerkgeskiedenis;

5. Aardrykskunde;

6. Beginsels van Natuurkunde en

7. Beginsels van die Engelse taal. ${ }^{32}$ ) 
Hierdie Admissie-eksamen moes inderdaad dien om die peil van die studie te verhoog, veral waar voorheen art. 8 van die Kerkorde van die Gereformeerde Kerk wat handel oor buitengewone gawes, sterk op die voorgrond gestaan het. Hierdie eksamen was inderdaad die eerste stap om die peil tot toelating te verhef tot die besit van 'n Matrikulasie-sertifikaat wat in 1879 vasgestel is.

Waar die Kuratore in hulle rapport „de School ernstig de belangstelling der Synode" aanbeveel het, kon hulle waarlik tevrede gevoel het met die werk wat daar verrig was.

In verband met die aanwysing van die twee professore is besluit dat die sinode self die teologiese professor sou aanwys, maar dat die Kuratore die literariese professor moes aanwys.

Vir die professoraat in die teologie is drie persone genomineer, $\mathrm{nl}$. ds. D. Postma, prof. S. van Velzen van Kampen, Nederland, en prof. H. de Cock, ewe-eens van Kampen. Ds. Postma is met 'n groot meerderheid van stemme verkies, maar in sy antwoord op die verkiesing het hy gevra om daarvan onthef te word, aangesien hy van mening was dat die tyd aangebreek het om 'n wetenskaplik beter gevormde man aan

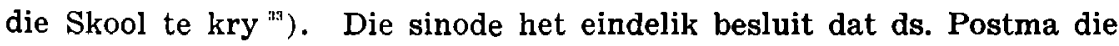
professoraat tydelik moes waarneem tot die volgende sinode, en daartoe het hy ingewillig.

Vir die opvulling van die pos van professor literarum het die Kuratore besluit om applikasies te vra en dat dit in Suid-Afrika sowel as in Nederland bekend gestel moes word. Op 'n buitengewone vergadering van dic liggaam gehou op 23 Mei 1876 is bogenoemde besluit geneem en op 'n spesiale sitting wat op 2 Oktober van dieselfde jaar gehou is, is die applikasie van P. Postma, B.A., aangeneem. Hy was die oudste seun van ds. D. Postma en het sy studie aan Gill College, Somerset-Oos, voltooi.

Die Skool het dus na 1876 heeltemal 'n nuwe fase ingegaan, en dat die verandering inderdaad 'n verbetering was, ly geen twyfel nie, want in die notule van die vergadering van die Kuratore, gehou op 6 Mei 1878, lees ons dat die Rektor die Kuratore gelukwens met die goeie uitslag van die eerste proewe van die literariese eksamen. ${ }^{34}$ ) En verder blyk uit die rapport van die Kuratore an die volgende sinode (1879) die volgende: Nadat verskillende gegewens in verband met studievorderinge vermeld is, lui die sewende punt van die rapport soos volg: 
„Uit de verschillende examina, in de laatste tijd afgelegd, blijkt dus duidelijk de goede werking van de nieuwe organisatie der School"..3)

Op advies van die Kuratore het hierdie sinode ook ' $n$ baie belangrike besluit geneem insake die toelatingseksamen tot die Teologiese Skool, $\mathrm{nl}$. ,dat er van zulk een persoon geeischt moet worden de vertoning van een certifikaat van het Universiteits Matriculatie examen. Evenwel met dien verstande, dat hij zich daarna onderwerpe aan een verder onderzoek door de Curatoren in die vakken, welke volgens voorschrift der Synode aangegeven zijn." ${ }^{39}$ )

Hierdie besluit het die verheffing van die studiepeil 'n stappie verder gevoer, want later sou dit op gelyke voet met B.A. gebring word, totdat dit eindelik bepaal is dat die B.A.-graad die toelatingsvereiste moet wees.

In die kuratoreverslag aan hierdie sinode word nog ' $n$ feit vermeld wat vir ons veral van belang is. Punt 4 van die rapport lui : „Ook is de School zoo gelukkig geweest dat 3 van hare studenten met goed gevolg hun Gouvernements Onderwijzerseksamen hebben afgelegd." ${ }^{32}$ )

Die verwagting van die oprigters van die Skool is dus nie beskaam nie, want meer en meer het die Teologiese Skool begin beantwoord a:an sy doel, nl. om naas opleidingsplek vir predikante ook te wees die plek waar jong manne gevorm kon word vir hulle lewensroeping op ander terreine van die lewe.

Op hierdie sinode moes nou die teologiese professor benoem word en weer is ds. D. Postma van Burgersdorp met 'n groot meerderheid van stemme aangewys. So het dit duidelik geword dat ds. Postma die volle vertroue van die Kerk geniet het, want hoewel hy keer op keer gevra het, maak my los van die werk sodat 'n man wat wetenskaplik beter toegerus is die werk kan aanvaar, het die Kerk hom maar weer aangewys as sy keuse. Ds. Postma het hom hierdie keer die benoeming laat welgeval om sodoende die eerste voltydse teologiese professor van die Skool te word.

Die professor in die litemariese departement het intussen voortgega:an met sy studie en in 1879 sy Kandidaatseksamen in die Teologie afgelê, om daarna as proponent beroepbaar gestel te word. Op 2 Feb. $\mathbf{1 8 8 0}$ het die Kuratore 'n buitengewone vergadering gehou, waarop die bedanking van prof. P. Postma behandel is en aan hom ontheffing van sy taak verleen is. Hy het kort daarna predikant geword van Burgersdorp en sodoende sy vader opgevolg aldaar. 
Die vakature is bespreek en met algemene stemme is toe benoem $\mathbf{M}$. Postma, broer van die vorige professor litterarum. Mnr. Postma het toe reeds die B.A.-graad besit en sou later nog verder gaan en die M.A.graad in Klassieke Tale verwerf. Hy het later die algemeen bekende ds. M. Postma van Johannesburg geword en was op sy beurt weer die vader van ons onlangse ontslape Rektor, prof. dr. F. Postma.

Die nuwe professor kon eers op 1 Julie diens aanvaar, hoewel hy reeds op $1 \mathrm{Mei}$ geinstalleer is. In die tussentyd het ds P. Postma die werk waargeneem.

In 1882 het die nuwe professor die Kuratore versoek om 'n gekwalifiseerde onderwyser an te stel aan die Teologiese Skool wat die opleiding van die jongelinge vir die Admissie-eksamen kon behartig en hulp kon verleen met die literariese vakke. Die Kuratore het hierdie saak baie duidelik gestel in hulle rapport aan die volgende sinode. ${ }^{a 8}$ )

Die bespreking van hierdie saak het 'n besonder belangrike wending geneem op die sinode. Daar is $\mathrm{nl}$. beskrywingspunt van die volgende inhoud behandel: „De Synode ga er nu toe over, aan de Theol. School onzer Kerk toe te voegen eene Opleidingschool voor onderwijzers, hoofdzakelijk ten dienste der buitengemeenten onzer Kerk." ${ }^{\mathfrak{a}}$ )

Toe die saak saam met die wat in die kuratorerapport voorkom behandel is, het die sinode 'n sub-kommissie benoem om daarop in te gaan. Genoemde komm. het 'n uiters belangrike rapport voor die sinode gelê wat ons hier net saaklik weergee:

Die komm. ag dit baie wenslik om so'n uitbreiding aan die Skool te bewerkstellig, maar aangesien dit 'n tweede professoraat in die Literariese Departement sal meebring, moet daarop gewys word dat die finansiële las te swaar sal wees vir die gemeentes; vir die teenswoordige moet dus daarvan afgesien word; die komm. voel egter dat onder die omstandighede die sinode daartoe moet oorgaan om 'n voorbereidende skool op te rig, soos versoek deur die professor literarum, al sou dit nie dadelik kon gebeur nie. ${ }^{\circ}$ )

$\mathrm{Na}$ bespreking van die rapport het die sinode die advies insake uitbreiding van die Skool aanvaar en sodoende afgesien van 'n tweede professoraat in die lettere of wetenskappe, en wat die laaste deel betref is besluit om ' $n$ deputaatskap te benoem wat op die ev. sinode moes rapporteer oor 'n voorbereidende Skool. ")

Prof. M. Postma het verder 'n veranderde skema vir die literariese studie aan die hand gedoen en dit is ook deur die Kuratore aanhangig 
gemaak op hierdie sinode. Die sinode het dit bespreek en goedgekeur en aangesien dit vir ons doel nogal belangrik is word dit hier saaklik weergegee:

A. Hollands :

i) Hollandse taalkunde, woordafleidings, ens.;

ii) Hollandse letterkunde;

iii) Oorsig van die geskiedenis van Nederland.

B. Latyn:

i) Poësie-een boek van Vergilius of Horatius;

ii) Prosa-een boek van die geskiedskrywer Livius; een filosofiese boek van Cicero of in die plek daarvan een van Cicero se redevoerings;

iii) Latynse spraakkuns-opstelle van Hollands in Latyn;

iv) Oorsig van die Romeinse geskiedenis

C. Grieks :

i) Poësie-een treurspel van een van die Griekse treurspeldigters en een boek van die Odysea of die Elias van Homeros;

ii) Prosa-een boek van die geskiedskrywers;

iii) Griekse spraakkuns-opstelle van Hollands in Grieks;

iv) Oorsig van die Griekse geskiedenis.

D. Mitologie;

E. Logika en Retorika:

F. Algemene Geskiedenis.

(Hebreeus is as vak in die teologiese studie betrek).

N.B. (1) Met die oog op die teenswoordige inrigting van die Skool het die professor geen Matematiese vakke in die skema opgeneem nie, ofskoon hy oortuig was van die noodsaaklikheid en die wenslikheid;

(2) Hierdie kursus kan in twee jaar of een en 'n halwe jaar afgeloop word. ${ }^{42}$ )

Met hierdie verandering is die onderwyspeil in die Literariese Departement aansienlik verhoog en dit is ook geen wonder dat op die Kuratorevergadering van 7 Mei 1883 die Rektor in sy verslag melding kon maak van 'n kandidaat wat hom voorberei vir die B.A.-graad van die Kaapse Universiteit nie. Die Rektor het in dieselfde rapport ook twee medaljes uitgeloof: 'n Silwermedalje aan die kandidaat wat in die Matrikulasie-eksamen met lof sou slaag en 'n goue medalje vir die kandidarat wat sy B.A.-graad met lof verwerf. ${ }^{13}$ ) So is van die kant van 
die professore ook doelbewuste pogings aangewend om die voorbereidende studie so deeglik as moontlik te maak. Nie net is die studente aangemoedig om 'n hoër studiepeil te bereik nie, maar ook die professore het daarin die voorbeeld gestel, veral prof. M. Postma. So kon die Rektor in Maart 1885 rapporteer aan die Kuratore dat prof. M. Postma sy M.A.-graad verwerf het. Hiervan het die Kuratore en later ook die sinode met groot dankbaarheid kennis geneem.

Op die sinode van 1885 het die Kuratore weer sekere wysiginge voorgelê vir goedkeuring. Dit betref die Admissie-eksamen en die Literariese eksamen. ${ }^{4}$ ) As veral die laasgenoemde verandering vergelyk word met die wat die vorige sinode goedgekeur het, blyk dit dat Suid-Afrikaanse geskiedenis by die Algemene gevoeg is, en verder word by vakke soos Grieks en Latyn doelbewus aangesluit by Matrikulasie.

In 1887 het die Kuratore besluit om 'n beurs van $£ 25$ per jaar toe te ken aan 'n student wat met lof geslaag het in die Matrikulasie-eksamen en verder is genotuleer dat 4 studente hulle voorberei vir die B.A.graad. ${ }^{45}$ )

In 1889 het prof. M. Postma sy proponentseksamen met goeie gevolg afgelê, en 'n beroep aanvaar. Die Kuratore het toe weer vir ds. $P$. Postma wat vroeër literariese professor was, beroep, maar toe hy die roeping nie aanvaar het nie, is sy broer S. Postma, B.A., aangewys.

In 1890 is professor D. Postma oorlede. Dit was 'n gevoelige verlies vir Kerk en Skool, want vir soveel jare het hy 'n prominente aandeel gehad in die sake van die Kerk en vanaf die stigting van die Skool in 1869 was hy verbonde daaraan. Sy plek is eers voorlopig opgevul deur die Kuratore met die benoeming van ds. J. L. Cachet en op die sinode van 1891 is hy permanent benoem.

Die sinode van 1894 was geroepe om sorgvuldige aandag te skenk aan die belange van die Skool. Daar was van die kant van die Kuratore skemas ter wysiging van sowel die admissie- as die literariese eksamen en verder ook een in verband met die opleiding van onderwysers. Daarbenewens was daar 'n hele aantal beskrywingspunte insake verskuiwing van die Skool, asook een wat gevra het vir die oprigting van 'n Christelike gimnasium in die Kaapkolonie. Aangesien hierdie sake te omvattend en ingrypend van aard was, is besluit om 'n kommissie van praeadvies te benoem wat op al die sake in moes gaan en rapport aan die sinode voorlê Aangesien hierdie rapport aan die sinode van so groot 
belang was, ook met die oog op latere verwikkelinge, haal ons dit hier in sy geheel aan:

„De Commissie door de Eerw. Synode benoemd om haar met advies te dienen op al de beschrijvingspunten betrekking hebbende op de Theol. School heeft de eer hiermede haar rapport te doen.

De Commissie heeft al de punten in ernstige en biddende overweging genomen en was zich bewust dat de bewaring van de eenheid der Kerk en de goede verstandhouding van de gemeenten in de drie landen in nauw verband met het besluit der Synode in deze zaak zullen zijn.

1. Ingevolge Beschrijvingspunten No. 2, 3 en 4 heeft de Commissie dus ernstig en biddend overwogen de verplaatsing der Theol. School maar is tot het besluit gekomen de Synode te moeten adviseren de Theol. School vooreerst te Burgersdorp te laten (gekursiveer in die Acta vanaf vooreerst te laten).

De Commissie heeft de beide voorgestelde plaatsen in ernstige overweging genomen, n.l. Pretoria en Middelburg (Kaap Kolonie) en is tot het besluit gekomen dat voor als nog er geene verplaatsing moet zijn.

Wat betreft Pretoria is de Commissie van oordeel dat eene verplaatsing voor als nog niet naar Pretoria kan plaats vinden om de volgende redenen:

a) Daar er reeds te Pretoria een Christelijk Gymnasium van Staatswege is, dat zeer veel overeenkomt met het literarisch departement onzer Theol. School, is een concurrentie van ons Literarisch Departement met die inrichting onwenschelijk.

b) Als er sprake kan zijn van de verplaatsing naar Pretoria, kan het alleen zijn van het Theol. Departement, en hoewel de Commissie van oordeel is dat er veel voor te zeggen is acht zij het voor het heden onmogelijk, daar de professoren onzer Theol. School elkander in de behartiging der onderscheiden klassen helpen, en het Theol. Departement voor als nog te klein is om alleen te staan.

c) Het leven te Pretoria is voor als nog te kostbaar en daardoor zou menig minder vermogend jongeling verhinderd worden opgeleid te worden.

Onder de voordeelen voor de verplaatsing naar Pretoria kan de Commissie opnemen.

1. De uitbreiding der Gereformeerde Kerk in de Z.A. Republiek.

2. De meerdere geschiktheid van Pretoria als eene Academie stad. 
3. De Hollandsch wetenschappelijke omgeving te Pretoria waarvan de studenten veel voordeel kunnen trekken.

Wat betreft Middelburg (Kaap Kolonie) is de Commissie van oordeel dat hoewel het levene te Middelburg goedkoper en aangenamer zou zijn dan te Burgersdorp, de toestanden te Middelburg niet zooveel van Burgersdorp verschillen om eene verplaatsing te rechtvaardigen en in dat geval het slechts een voorkeur van plaats en niet van taal en van beginsel zou zijn in tegenoverstelling van Pretoria.

2. De Commissie heeft in ernstige overweging genomen Beschrijvingspunt No. 1 en is van oordeel dat het bezwaar daar genoemd vooral van de Z.A. Republiek gegrond is en dat er ontegenzeggelijk in onzen bestaanden toestand eene onbillijkheid is, die weggenomen moet worden Het is de Commissie echter gelukt om in overleg met de $\mathrm{C}$ aratoren vooreerst eenigszins in dat bezwaar te gemoet te komen. De Commissie was eenparig van de overtuiging dat ons doel moet zijn in de toekomst de verwezenlijking van Beschrijvingspunt No. $1 \mathrm{nl}$. eene afzonderlijke Theologische School en een Gereformeerd Gymnasium onder beheer en toezocht van onze gemeenten in de Kaap Kolonie.

Als overgangs matregel adviseert de Commissie het volgende:

a) Het tegenwoordig literarisch departement worde in twee deelen gesplitst-een lager literarisch en een hooger literarisch departement. Het lager literarisch departement zal gaan tot het Matriculatie Examen. In het hooger literarisch departement zullen de studenten voorbereid worden voor het Literarisch Examen dat Admissie Examen tot de studie in de Theologie is en waarvan het Hollandsch het medium blijft.

b) Het lager literarisch departement moet ten spoedigste door de Algemeene Vergadering der Kaap Kolonie voor haar eigene rekening overgenomen worden waartoe deze Synode de Algemeene Vergadering der Kaap Kolonie bij hare eerste zitting reeds zal verzoeken.

3. Wat Beschrijvingspunt No. 5 betreft oordeelt de Commissie dat het gewijzigde Schema voor het Literarisch Examen voor de Synode gelegd tegemoet komt zoover als in de bestaande omstandigheden mogelijk is, daartoe wijzende op de hoogere literarische afdeeling die nu meer Hollandsche studie eischt en op het reeds bestaande besluit dat certificaat van tweede graad in de letteren en wetenschappen van de Zuid-Afrikaanse Republiek voldoende is. 
4. De Commissie beschouwt dat wat Beschrijvingspunt No. 6 betreft met de oplossing van punt 5 daaraan beantwoord is.

Beschrijvingspunten 7 en 9 acht de Commissie niet naar haar verwezen.

5. Op punt 7 in het verslag der Curatoren met betrekking tot nieuwe gebouwen voor onze Theol. School en woning voor den Professor Theologicus adviseert de Commissie dat met het oog op de al of niet verplaatsing der Theol. School er nu geene nieuwe gebouwen opgetrokken worden, maar dat de Curatoren gelast worden eene zekere som jaarlijks te geven voor huur van een woning van den Professor Theologicus tot de volgende Synode en insgelijks, indien mogelijk eene som voor huur van gebouwen voor de Theol. School.

6. De Commissie adviseert de aanname van de gewijzigde schemas voor het Admissie Examen en het Literarisch Examen in punt 8 van het verslag der Curatoren.

7. De Commissie adviseert ten sterkste dat de som van $£ 275$ sterling per jaar onmiddelijk beschikbaar gesteld worde voor de Curatoren $\mathrm{cm}$ een Assistent te benoemen voor den Professor Literarum. Het werk van het Literarisch Departement is te omvangrijk en de vakken te veel en te verschillend om door één persoon behartigd te worden.

Men heeft slechts als voorbeeld te nemen het Staat Gymnasium te Pretoria, dat nog maar 2 jaren oud zijnde, 5 Docenten heeft.

8. Ten slotte geeft de Commissie de $S_{j}$,node in overweging de aanstelling van drie Commissieleden uit de Kaap Kolonie om met de Algemene Vergadering aldaar in nadere onderhandeling te treden, het hierboven aangehaalde plan van Theologische Afdeeling en Gereformeerd Gymnasium voor te bereiden en op de e.k. Synode verslag van hare werkzaamheden te doen ")

Die sinode het hierdie rapport baie deeglik bespreek en uit die feit dat daar ses voorstelle hieroor ingekom het blyk genoegsaam van hoe groot belang die hele aangeleentheid was. Die voorstel wat aangeneem is, lui soos volg:

„Het advies der Commissie worde aangenomen, alleen worde in punt $\because$ in plaats van ,om één assistent" de woorden gesteld „ter verkrijging van assistentie." "a)

Vir ons doel is sekere van die sake vervat in bovermelde rapport van direkte belang en gevolglik skenk ons hier aandag daaraan. 


\section{Die skema vir die Admissie-eksamen ${ }^{47}$ )}

Die aanhef van die skema is besonder belangrik, want daarin word sekere erkende eksamens in die verskillende state genoem, nl. Elementêre Eksamen van die Kaapse Universiteit-Kaapland; die Derde Klasse Onderwijsers (aanvulling) eksamen-Transvaal en in die O.V.S. die Derde Klas Onderwyserseksamen. As iemand bewys kon lewer dat hy een van genoemde eksamens met goeie gevolg afgelê het, kon hy toegelaat word tot Propedeutiese studie aan die Skool. As dit nie kon nie, moes die Admissie-eksamen wat in die skema vervat is, eers afgelê word.

\section{Die skema vir die Literariese eksamen ${ }^{46}$ )}

Hierdie skema verskil nie veel van die wat ons vantevore al aangehaal het nie. Dat die peil van die studie egter stadig maar seker verhoog is, blyk uit die volgende: By die Latyn en Grieks is 'n N.B. geplaas van die volgende inhoud:

„De papieren van Grieksch en Latijn zullen behelzen vertaling uit de opgegevene stukken en vragen betreffende de auteuren, taal en inhoud der stukken. Dan zal er nog één algemeen papier zijn, waarin gegeven zullen worden stukken ter vertaling ad aperturam uit het Grieksch en Latijn in het Hollands en vice versa, alsmede algemeene vragen over taal en constructie.

Die vroeëre skemas het net melding gemaak van opstelle van Hollands in Latyn of Grieks.

Verder is dit opmerklik dat in die skema nou drie nuwe afdelings ingevoeg is, t.w. Bybelse geskiedenis, geskiedenis van Suid-Afrika en Wysbegeerte. Die afdeling Mitologie het nou verdwyn en by Logika het Retorika weggeval, want in die nuwe skema word dit net Logika genoem.

\section{Die skema vir die Onderwyseksamen. ${ }^{17}$ )}

Hierdie belangrike stuk, wat 'n sprekende bewys lewer vir die buitengewone karakter van die Teologiese Skool en veral in aanduiding is dat die Literariese Departement meer moes doen as om net aanstaande predikante aan die nodige kennis van die ou tale te help, is nie deur die sinode aanvaar nie en die volgende besluit is daaroor geneem: „De Synode besluit in deze zaak, hangende de uitvoering van het advies der Commissie re Theol. School, niet te treden omdat het het aangenomen advies zal bemoeiliken." "a) 
Daarmee was die saak egter slegs voorlopig van die tafel af, want later sou die behoefte daaraan altyd meer en meer gevoel word.

Soos tevore aangedui het die sinode egter vergunning gegee om assistensie te verleen aan die professor literarum met die gevolg dat op die vergadering van die Kuratore gehou op 10 Junie 1895 besluit is dat studente P. C. Snyman en J. A. du Plessis, wat in die hoedanigheid reeds besig was, nog verder moes aanbly. Die jaar daarop het die Kuratore egter besluit om 'n tweede professor in die Literariese Departement aan te stel, maar dat vir daardie doel 'n buitengewone vergadering gehou sou word. Die saak het egter nie so gou in orde gekom nie en eers in 1897 toe prof. S. Postma 'n beroep na Middelburg (Kaap)) aangeneem het, is dit weer aan die orde gestel. Na rype beraad is in 1898 student P. C. Snyman verkies tot literariese professor en as tweede professor in die lettere is aangewys J. A. du Plessis.

Die volgende jaar het die Engelese oorlog uitgebreek en daardeur het die werksaamhede aan die Skool nagenoeg tot stilstand gekom.

As ons dus die vooruitgang van die Skool tot aan die end van die $19 \mathrm{e}$ eeu moet opsom, kan ons vasstel dat die Literariese Departement van de Skool gestadig vorentoe gebeur het: Die peil van die propedeutiese studie is altyd hoër gestel, só selfs dat studente aangemoedig is om vir B.A. te studeer; diegene wat nie vir 'n graad gewerk het nie, moes twee jaar aan die literariese eksamen wy en onderwysers is ook reeds aan die Skool opgelei. Stemme het altyd meer en meer opgegaan dat 'n professor in Pedagogiek benoem moes word, maar die Kerk het daarvoor nog teruggedeins.

Toe die oorlog uitgebreek het, het die Skool as gevolg van sy uitgesproke Afrikaanse gees en gesindheid, 'n moeilike tyd tegemoet gegaan. Uit die rapport van die Rektor wat hy voor die eerste Kuratorevergadering, wat in 1902 gehou kon word, gelê het, blyk die volgende:

$\mathrm{Na}$ die uitbreek van die oorlog het die Transvaalse en Vrystaatse studente vertrek; die ander studente het gevra dat die Skool gesluit moes word, maar die professore het dit nie gerade geag nie; in November 1899 is Burgersdorp deur die Burgerkommando's beset en toe is die Skool gesluit aangesien die professore en studente by die Ambulanskorps aangesluit het; na die burgers teruggetrek het, is die Skool weer geopen, maar kort daarna deur die Engelse militêre owerhede wat toe die dorp beset het, gesluit; prof. Cachet is in die gevangenis geset op aanklag van hoogverraad, maar die klag is later teruggetrek 
sodat hy vry kon uitgaan; student W. de Klerk, die later so bekende ds. W. J. de Klerk, is gevange geneem en weggestuur na King Williamstown waar hy 'n aantal maande moes vertoef; 'n drietal studente het gesneuwel op die slagveld en 'n tiental is as krygsgevangenes weggestuur na verskillende oorde. ${ }^{50}$ )

Die Kuratore het besef dat daar deeglike aandag geskenk sal moet word aan die aangeleenthede van die Skool en die volgende besluit wat op die voormelde vergadering geneem is, wys duidelik in watter rigting hulle gedink het: „De Curatoren achten het zeer wenschelijk dat er pogingen aangewend worden om behalve de gewone kerkelijke bijdragen, ook speciale giften en vaste bijdragen van vrienden en begunstigers te verkrijgen voor de Theol. School en vraagt de Alg. Vergadering van de Kaap Kolonie om daartoe mede te werken." ${ }^{51}$ )

Voordat hierdie saak egter aagepak kon word het daar 'n ernstige wending gekom wat alle aandag geverg het, nl. die verplasing van die Teologiese Skool.

III. DIE SCHOOL GEDURENDE DIE TYDPERK $1903-1920$.

\section{A. Die verplasing van die Skool na Transvaal.}

Die saak van verplasing van die Teologiese Skool is reeds op die sinode van 1894 baie deeglik bespreek en volgens die advies van die ad hoc-kommissie wat ook deur die sinode aanvaar is, moes die Skool vir eers nog maar in Burgersdorp bly. Die saak was dus nie van die baan nie, want op die sinode van 1897 is dit weer te berde gebring. Ook hierdie sinode het ' $n$ kommissie benoem om aan die hele aangeleentheid aandag te gee en te adviseer (artt. 55, 56). Andermaal is die sinode geadviseer om die Skool maar voorlopig in Burgersdorp te laat bly en dat die volgende sinode weer daarop moes terugkom, terwyl 'n kommissie intussen die koste verbonde aan sodanige verplasing moes bereken. ${ }^{\mathrm{s} 2}$ ) Die oorlog het intussen uitgebreek sodat die saak nie weer aandag kon geniet nie. Toe die Kuratore weer in 1902 na die verwoestende oorlog kon vergader, moes hulle aandag skenk aan die belange van die Skool aangesien sake allesbehalwe normaal verloop het gedurende die oorlogsjare.

Sonder aat daar besondere redes vermeld staan vind ons egter in die notule van 'n Buitengewone vergadering gehou op 11 Februarie 1903 die volgende besluit: „De Curatoren besluiten om aan de respective Algemeene Vergaderingen der drie Staten mede te deelen, dat zij (de 
curatoren) na alle zaken in hare vergadering van $11 \mathrm{Feb}$. j.l. in ernstige overweging genomen hebbende tot de overtuiging gekomen zijn dat de Theol. School verplaatst wordt en dat zij beschouwen dat Middelburg K.K. de geschikste plaats is om de School te vestigen en zij daarom de respective Algemeene Vergaderingen verzoeken om zich beslist uit te spreken over deze zaak opdat de Curatoren daardoor indien mogelijk, informel machtiging bekomen om de zaak uit te voeren dewijl het nog onzeker is wanneer de ev. Synode zitten zal en de zaak om verschillende redenen geen uitstel kan lijden." ${ }^{\text {s3) }}$

Hiermee was die saak van verplasing van die Skool meteen weer op die voorgrond. Pogings is in die werk gestel om grond by Middelburg daarvoor aan te koop en 'n Buitengewone kuratorevergadering is selfs op 20 Feb. 1903 te Middelburg gehou vir daardie doel. ")

Toe die saak rugbaar geword het, het daar egter ander aanbiedinge na vore gekom: Steynsburg het bv. 'n pragtige aanbod gemaak in verband met terrein nodig vir die School, sodat die Kuratore op 'n vergadering gehou op 10 Junie 1903 besluit het om Steynsburg se aanbod te aanvaar en die Skool daarheen te verplaas. Die Sinodale deputate benoem in 1897 om die koste van verplasing te bereken, het ook in Des. 1903 saam met die Kuratore vergader en aangesien daar geen ander opening was nie, besluit om aan te beveel om Steynsburg te kies as die nuwe tuiste van die Skool..$^{\mathrm{st}}$ )

Die Algemene Sinode is inmiddels opgeroep om op Middelburg (Kaap) te vergader en wel op 24 April 1904 e.v.d. Op die sinode sou die hele saak van verplasing van die Skool behandel en beslis word.

Die saak is aanhangig gemaak in die Rapport van die Kuratore en daarin is die volgende gronde vir verplsing van die Skool van Burgersdorp na Steynsburg aangevoer:

,a) De mogelijkheid om geschikt terrein in Burgersdorp te vinden;

b) Het gunstige aanbod van Steynsburg;

c) De noodzakelijkheid van het logieshuis in Steynsburg's voorstel vervat." ${ }^{\text {so }}$ )

Op die sinode het daar ook ander stukke gedien:

i) 'n Brief van die kerkraad van Burgersdorp waarin aangebied word om te sorg dat die nodige grond vir 'n nuwe skoolgebou verkry kan word. ${ }^{\text {s7}}$ ) en 
ii) 'n brief onderteken deur J. D. du Toit en T. G. Schutte namens die kerkruad van Potchefstroom waarin 'n bedrag van $£ 3,010$ aangebied word namens die gemeentes Potchefstroom ( $£ 1,150)$; Pretoria $(£ 1,000)$; Rustenburg ( $£ 600$ ); Heidelberg ( $£ 190$ ) en Wolmaransstad ( $£ 70)$; verder is drie aanbiedinge van grond daarin vermeld:

a) Van die Gereformeerde gemeente Potchefstroom om op die kerkplein te bou;

b) van die Stadsraad van Potchefstroom; en

c) van die Landbou-sindikaat. ${ }^{38}$ )

Die sinode moes dus besluit of die Skool verplaas sou word en indien wel moes gekies word tussen Steynsburg en Potchefstroom.

$\mathrm{Na}$ 'n uiters breedvoerige bespreking is besluit: „De School worde wel verplaatst." " ${ }^{\text {s") }}$ Daarna is besluit oor die plek en die voorstel dienaangaande het net gelui: „De School worde na Potchefstroom verplaatst." " Hierdie voorstel is aangeneem. Daarmee was die saak dus beslis en kort daarna is die nodige stappe gedoen om die geboue te Potchefstroom op te rig.

B. Die verwikkelinge aan die Skool self voor verplasing.

Ons het reds gesien dat die Kuratore op hulle eerste vergadering na die oorlog besluit het om pogings in die werk te stel om spesiale gifte en vaste bydrae van vriende en begunstigers te verkry. ${ }^{67}$ ) Net die volgende jaar het prof. Snyman ontslag aangevra aangesien hy 'n beroep na Steynsburg aanvaar het. As opvolger is aangewys D. Postma, B.A. (die seun van ds. M. Postma), maar slegs as assistent en nie as professor nie.

Dat in die Literariese Departement ook aandag geskenk is aan die Natuurkundige vakke blyk uit die feit dat op die Kuratorevergadering van 10 Junie 1903 besluit is dat dr. J. D. du Toit, wat toe nog in Nederland was, die nodige instrumente vir natuurkundige studie moes aankoop. ${ }^{\text {a2 }}$ )

Op dieselfde vergadering is ook 'n uiters belangrike besluit geneem, nl. om die professoraat in die Lettere aan te bied aan F. Postma met ingang Februarie 1904 op voorwaarde dat hy sy Kandidaatseksamen aan die Vrye Universiteit van Amsterdam sou slaag. ${ }^{(3)}$ ) Hier kry ons dus die begin van 'n verbinding tussen F. Postma en die Skool wat van besonder groot betekenis sou wees, aangesien dit die lewenstaak van Postma sou blyk te wees om die Departement van Lettere te dien in al die verskillende stadia totdat dit 'n volwaardge Universiteit sou wees. 
Op die Kuratorevergadering van 9 Des. 1903 is die antwoord van F. Postma behandel waarin hy hom die roeping laat welgeval, maar daar

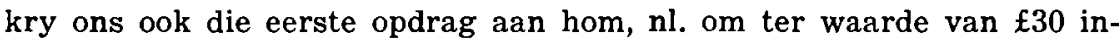
strumente vir die onderwys in Natuurkunde aldaar aan te koop. ")

Die Kuratore het by hierdie geleentheid ook aan prof. J. A. du Plessis ontslag verleen omdat hy 'n beroep aangeneem het en in sy plek is D. Postma, B.A., aangestel.

Waar in 1902 besluit is om pogings in die werk te stel om persone te werf wat as donateurs van die inrigting sou optree, vind ons in April 1904 die resultaat daarvan, nl.dat die Christelijk Nationale Boerencomité die instrumente vir bestudering van Natuurkunde geskenk het.

C. Die Teologiese Skool te Potchefstroom tot 1921.

Teneinde die sinodebesluit uit te voer is 'n kuratorevergadering belê te Potchefstroom op 27 Junie 1904 Op hierdie vergadering is nie net aandag geskenk aan die geboue ens. nie, maar is ook besluit oor die ontslag van prof. D. Postma wat inmiddels 'n beroep na Krugersdorp geneem het (art. 10).

Verder is ook besluit tot die benoeming van 'n "Mathematische" professor, wat selfs in Nederland gewerf moes word as dit nie anders kon nie.

Die Teologiese Skool is op 13 Febr. 1905 te Potchefstroom geopen, waar intussen die nodige geboue opgerig is, nl. 'n skoolgebou en 'n woning vir die Rektor. Prof. F. Postma het toe ook diens aanvaar en onder sy leiding sou die Literariese Departement stadig maar seker vorentoe beur.

Op die buitengewone vergadering van die Kuratore, gehou tydens die opening van die Skool, is as assistent vir Matesis en Fisika aangestel 'n sekere A. H. Kooijker; verder is J. Kamp as assistent aangestel en nog een van die senior studente kon deur die professore aangewys word om assitensie te verleen in die Literariese Afdeling. ${ }^{15} \mathrm{a}$ ) Die opvulling van die professoraat in Matesis en Fisika het in Des. 1905 plaasgevind toe A. P. C. Duvenage aangestel is en J. Kamp tot dosent verhef is. ${ }^{65}$ ) Die student is ook nog vir 'n jaar aangewys as assistent. Intussen is ook 'n losieshuis gebou waardeur die vraagstuk van losies vir die studente opgelos is.

Van nou af ontmoet ons in die notule van die Kuratorevergaderinge meer en meer die probleem van laboratoriumuitrusting en van tyd tot tyd moes die Kuratore daaraan aandag skenk. 
Aan die Skool het sake normaalweg verloop en volgens die rapporte van die Rektor elke jaar aan die Kuratore het dit geblyk dat 'n gestadige groeiproses voortgeduur het.

In 1909 is besluit dat daar ook dames toegelaat mag word en in dieselfde jaar is weer ernstige aandag geskenk aan die toerusting van Christelike onderwysers aan die Skool. ${ }^{65} \mathrm{c}$ )

In 1910 het die Rektor, prof. Cachet, in die laaste rapport wat hy in dié hoedanigheid sou lewer, die aandag gevestig op 'n saak wat as dit só sou deurgaan die Literariese Departement van die Skool ernstig sou benadeel. Hy het nl. die aandag gevestig op die nuwe Universiteitswet wat toe in voorbereiding was. Onder die ou Universiteitswet was die toestand soos volg: Die Universiteit van die Kaap die Goeie Hoop was die enigste eksaminerende liggaam en alle studente moes daardie eksamens aflê, afgesien van waar hulle ook hul opleiding geniet het. Onder die nuwe wet sou daar drie Universiteite tot stand kom, nl. die Universiteit van Suid-Afrika wat 'n samegestelde inrigting sou wees en dié van Kaapstad en Stellenbosch. Elkeen van die drie sou afsonderlik eksamineer en studente wat nie aan een van die drie ingeskrywe was nie, sou dan verplig wees om as eksterne kandidate die vraestelle van één van die s.umestellende kolleges van die Universiteit van S.A. af te skrywe. Dit sou dan beteken dat die studente van Potchefstroom geheel en al ekstern sou moet skrywe en na alle waarskynlikheid die vraestelle van die Transvaalse Universiteitskollege. Die Kuratore het blykbaar dadelik die dreigende gevaar ingesien, want 'n kommissie van twee lede is aangewys om die hele aangeleentheid met die Minister van Onderwys te gaan bespreek. ${ }^{66}$ ) Hierdie saak sou van nou af baie tyd van die Kuratore in beslag neem.

Dat daar egter behoefte was aan meer fasiliteite aan die inrigting, blyk uit die volgende besluit van die Kuratore, geneem op 6 Des. 1911: „De Kuratoren spreken de wenselikheid uit van de aanstelling van een Prof. aan de Teol. School die in bisonder belast zal zijn met de opleiding voor ' $t$ onderwijsambt. Zij dragen het aan de Senaat op om met de gemeenten over deze zaak te korresponderen en zelf de gemeenten te ontmoeten met 't oog om 'n Fonds voor dit doel in te samelen." 67)

Die bespreking het dus gegaan oor die aanstelling van 'n professor in opvoedkunde en aangesien die saak van so groot belang was, is opdrag gegee aan die personeel van die Skool, wat intussen gekonstitueer is in 'n Senaat, om die sak self te propageer onder die gemeentes en 
selfs pogings aan te wend om 'n fonds daarvoor in te samel. Dit was 'n nuwe wyse van optrede. Tot sover het die Kuratore nog altyd self die inisiatief geneem en sake van die aard voor die sinode gelê en pas daarna is dit na buite gepropageer. Nou egter word 'n ruime mate van selfstandige optrede aan die Senaat van die Skool toegeken, sodat fondse ingesamel kon word vir die nuwe leerstoel.

Op hierdie vergadering is verder ook verlof toegeken aan prof. F. Postma om na Nederland te gaan vir sy doktorsgraad.

In 1913 is op die Algemene Sinode 'n aantal baie belangrike sake deur die Kuratore aanhangig gemaak:

i) Die aanstelling van 'n tweede Teologiese professor.

$\mathrm{Na}$ die aftrede van prof. Cachet is dr. J. D. du Toit aangewys as sy opvolger terwyl prof. Cachet ook nog deeltydse hulp verleen het; in 1912 is hy egter oorlede en nou is die sinode versoek om 'n tweede professor in die Teologie aan te wys; die sinode het die versoek bewillig en toe is dr. P. C. Snyman verkies, maar toe hy hom die benoeming nie laat welgeval het nie, is dr. S. O. Los verkies. ${ }^{68}$ )

ii) Die Literariese Departement.

Die las van die Literariese Departement is altyd meer en meer gevoel en keer op keer moes die Kuratore aandag skenk aan die uitbreiding van leerkragte in daardie afdeling, daarom is dit verklaarbaar dat die Kuratore begin dink het aan subsidie van die kant van die Staat vir hierdie afdeling van die Skool. So moet ons die volgende aanbeveling van die Kuratore besien: „De S'jnode oorwege de wenslikheid voor de Kuratoren om subsidie van de Regering aan te vragen voor ons hooger literaries onderwys, en wijze de weg aan waarop deze Subsidie door ons kan worden aanvaard." * Om die uitdrukking ,ons hooger litteraries onderwijs" te kan verstaan, moet ons hier net aanstip dat die Kuratore ' $n$ aantal jare tevore die Literariese Departement in twee gedeel het, nl. die laer literaries wat afgesluit het met Matrikulasie en die hoër literaries wat dus post-matrikulasie was. Dit was dus die deurvoering van die beleid wat die sinode van 1894 op advies van die kommissie ad hoc goedgekeur het.

In die feit dat die Literariese Departement altyd meer en meer aandag geverg het, moet ons die gesonde groei van hierdie afdeling van die Skool opmerk en hierdie versoek aan die sinode was 'n duidelike 
vingerwysing dat die Kuratore besef het dat die Kerk nie sal kan tredhou met die finansiële laste verbonde aan so'n groeiende instelling nie. Die sinode het die versoek aangevoel as 'n uiters delikate saak en gevolglik is dit eers weer verwys na die Kuratore vir prae-advies. Die Kuratore het volgens die notule van 'n vergadering wat tydens die sinodesitting te Steynsburg gehou is, wel ' $n$ besluit geneem om as advies aan die Sinode voor te lê wat as volg lui: „De Kuratoren adviseren de Sinode, om hen op te dragen bij de regering of Parlementsleden stappen te doen, opdat de studenten aan de Theol. School het recht behouden om de staatseksamens af te leggen, en om subsidie voor 'n Literariese Departement aan te vragen mits ons beginsel en vrijheid van bestuur gehandhaafd blijven." ${ }^{70}$ )

of die Sinode hierdie advies goedgekeur het staan nie in die offisiële Acta nie, maar die feit dat die Kuratore voortgegaan het met die saak is genoegsame aanduiding dat dit wel die geval was.

Op die Sinode is ook nog ' $n$ ander saak behandel, sonder dat die Kuratore dit daar direk aanhangig gemaak het.

In aansluiting by punt 2 van die Kuratorerapport wat gehandel het oor die studente wat intussen geslaag het en die getalle wat ingeskrywe was, is die vraag gestel hoe die Kuratore moes optree teenoor die te stigte Universiteit van Suid-Afrika en daarop is geantwoord: „Met betrekking tot de oprichting van een Universiteit en ons standpunt tegenover die universiteit, wordt het de Kuratoren opgedragen deze Synode met advies te dienen." 71) Hierdeur het die Kuratore dus opdrag ontvang "deze Synode" sou ons geneë wees om af te lei dat die saak nog weer voor die Sinode moes kom, maar blykens die notule van die Kuratore het hulle nie aandag gegee aan die saak terwyl die Sinode nog in sitting was nie.

Nieteenstaande die feit dat die swaard van Damocles altyd meer en meer sigbaar geword het bokant die Literariese Departement namate die nuwe universiteitswet gevorder het, het sake daar tog nie tot 'n stilstiand gekom nie.

Aangesien daar onvoorsiene hulp opgedaag het van die kant van die "Vereeniging Zuid-Afrikaansche Voorschotkas" was dit moontlik om lektore Le Roux en Boshoff aan te stel en sodoende versterking te bring in die geledere van die Kollege-departement soos dit nou meer en meer genoem word in die notule van die Kuratore. Uit die besluit wat die Kuratore geneem het om hulle dankbetuiging hiervoor te betuig, kom 
die ideaal wat agter die strewe van die Kuratore se optrede gesoek moet word, tot openbaring; daarom haal ons dit hier a.an: „Op voorstel van ds. W. Postma wordt een onbestreden motie van dank aan de Senaat voor zijn bemoeiing tot bevordering van 't Kollege Departement sta:ande aangenomen. Verder spreekt 't Kuratorium zijn hartelike dank uit voor de steun aan 't Kollege Departement van de Theologische School verleend door de Vereeniging Zuid Afrikaansche Voorschotkas en spreekt zijn overtuiging uit dat die steun veel zal bijdragen tot bevordering van Kristelik Nationale beginselen onder 't Hollandsch Afrikaansch volk alsmede van de Hollandsche Taal." ${ }^{72}$ )

In die jaar het die Senaat ook berig ontvang dat die Propedeutiese en die Kandadaatseksamens van die Teologiese Skool erken word aan die Vrye Universiteit van Amsterdam. Dit was ook 'n versterking wat juis in die naderende krisisjare gekom het. ${ }^{73}$ )

En dat dit die Kuratore erns was met die Christelike karakter van die inrigting blyk afdoende uit die volgende: Die Senaat het naamlik versoek dat die Kuratore reëlings moes tref om die Christelike karakter beter tot sy reg te laat kom, waarop die Kuratore besluit het: „Er wordt ernstiglijk bij de Senaat op aangedronge om zoodanige regelingen te treffen dat 't Christelijk karakter van de School beter tot zijn recht komt." 74 )

Op 7 Feb. 1917 het prof. Boshoff sy professoraat aanvaar met 'n rede oor: „Die Metode van ondersoek na die ontstaan van die Afrikaanse taal." Verder is in dieselfde jaar ook pastor Kohl aangestel as deeltydse dosent in Duits. Die Departement van Matesis en Natuurwetenschap het van tyd tot tyd aandag geniet, omdat die gelde gevind moes word vir die uitrusting van die laboratoria en dikwels is ook gespreek oor die afskaffing van hierdie departement, maar dit kon moeilik geskied en onder omstandighede is dit tog voortgeset.

In 1918 het die Kuratore die wenslikheid uitgespreek dat die studente eers die B.A.-graad moet verwerf voordat hulle oorgaan tot die teologiese studie. Die Senaat het opdrag gekry om die besluit onder die aandag van die studente te bring.

In 1919 is berig ontvang dat prof. F. Postma deur die Senaat van die Vrye Universiteit gevra is om hom verkiesbaar te stel vir die leerstoel in die Klassieke Tale aan die V.U. Hy het dit egter van die hand gewys en verkies om aan die Teologiese Skool te bly voortarbei. Hiervan het die Kuratore later met groot dankbaarheid kennis geneem. 
Op die vergadering van die Kuratore gehou in Mei 1919 het die Senaat gerapporteer dat die studentetal gestyg het tot 39 ; maar in die rapport wat die Kuratore voor die vervroegde sinode te Colesberg in 1920 gelê het, was die studentetal aan die end van die tweede kwartaal slegs 25, sodat dit dus duidelik geblyk het hoe nadelig die Kollegedepartement getref is deur die nuwe wet op Hoër Onderwys. Volgens daardie laaste rapport voordat inkorporasie plaasgevind het, het die Kollege toe reeds onder 'n aparte Raad bestaan en die raadslede was: Ds. J. A. du Plessis, ds. N. H. v.d. Walt, ds. D. N. Kotze, mnr. P. Stoker, mnnr. P. L. Yssel, prok. P. Lion Cachet en van Regeringsweë is benoem die here J. P. Nel en I. Meijer.

Die personeel van die Kollege het bestaan uit:

I Doserend: Proff. F. Postma, J. Kamp, P. Duvenage en S. P. Boshoff; lektore: J. C. van Rooy, H. G. Schulze, D. J. du Plessis, G. Eisselen en pastor Kohl;

II Administratief: Ds. W. J. de Klerk, Registrateur.

D. Skeiding van die Teologiese Skool en die Literariese Departement

Tevore is reeds daarop gewys hoedat die Kuratore die kwessie van subsidie vir die Literariese Departement op die Sinode van 1913 aanhangig gemaak het het toe die volgende voorgelê: „De Synode overwege de wenslikheid voor de Kuratoren om subsidie van de regering aan te vragen voor ons hooger litteraries onderwijs, en wijze de weg aan waarop deze Subsidie door ons kan worden aanvaard." ${ }^{35}$ Die Sinode het dit wel oorweeg maar wou nie oorhaastig daarin handel nie, vandaar die besluit dat die Kuratore eers vooraf daaroor moes beraadslaag en die Sinode van advies moes bedien. ${ }^{70}$ )

Dieselfde Sinode het ook na aanleiding van die kuratorerapport besluit oor die gedragslyn ten opsigte van die op te rigte universiteit. ${ }^{77}$ ) Hierdie besluit het ten opdrag bevat aan die Kuratore om die Sinode van advies te dien.

Hierdie gebeurtenisse was slegs die voorspel tot die werklikheid wat weldra in alle erns die aandag van die Kuratore en die Sinode sou verg. Uit die onderhandelinge wat intussen plaasgevind het tussen 'n kommissie van die Kuratore en die Owerheid het dit geblyk dat die Minister van Onderwys die eis gestel het dat die Literariese Departement geheel en al losgemaak moes word van die Teologiese Skool voordat enige subsidie van die kant van die Owerheid oorweeg kan word. Die Kuratore het dan ook geen beswaar ingebring om aan die eis te voldoen nie, 
mits hulle die lede van die bestuur kon benoem as dit kon lei tot affiliasie van die Kollege met die Noordelike Universiteitskollege ${ }^{78}$ ) Vir hierdie doel is ' $n$ kommissie benoem om verder te handel in die saak.

Die Sinode van 1916 was op hande en die Kuratore moes die Sinode adviseer insake die universiteitssaak. Uit die stuk wat die Kuratore aan die Sinode voorgelê het, blyk dat die onderhandeling met die Regering oor die saak voortgeduur het, maar dat weinig vordering gemaak is, omdat die hele saak van die universiteit nog so onseker was; die saak het egter nou weer ernstig geword en dit kon moeilik uitgestel word; gevolglik vra die Kuratore dat 'n kommissie benoem moet word wat gemagtig sal wees om alle voorstelle aangaande subsidie, affiliasie en samewerking in oorweging te neem en daaroor te besluit op so'n wyse dat die medeseggenskap van die Kerk vernaamlik tot handhawing van die beginsels, bewaar mag bly en dat hierdie kommissie sal bestaan uit die Kuratore, die Senaat van die Teologiese Skool en ses lede deur die Sinode te benoem. ${ }^{79}$ ) By hierdie rapport van die Kuratore aan die Sinode het nog 'n vry ernstige aanvulling gekom as gevolg van die feit dat prof. F. Postma op 'n vergadering van die Kuratore tydens die Sinode 'n uiters belangrike rapport aan hulle voorgelê het: Prof. Postma het uit 'n brief wat hy van die Minister van Onderwys ontvang het, die volgende informasie verstrek:

Dat dit onmoontlik sou wees vir die studente van Potchefstroom om eksamens te doen volgens die universiteitswetsontwerp wat toe onder behandeling was deur die Parlement en verder oor moontlike affiliasie van die Literariese Departement met die Federale Universiteit.

Aanvullend hierby het ds. P. Postma ook rapport gelewer insake sy onderhandeling met die Regering in Kaapstad: Aan hom is die versekering gegee deur die Minister dat wanneer die wetsontwerp in komitee behandel word, hy ' $n$ amendement sou aanneem wat die opening sou laat aan enige Kollege om later in te kom in die Federale Universiteit; die Minister het verder die weg daartoe aangewys deurdat die Kerk moes afsien van die sektariese beginsel en dat die moontlike inkorporasie moes geskied deur middel van 'n Private Wetsontwerp; verder sou volgens art. 18 van die Universiteitswetsontwerp onder sekere voorwaardes studente toegelaat word om as eksterne kandidate eksamens te mag doen; ingeval van inkorporasie sou 'n Kollege-Raad ingestel kon word wat uit 9 lede bestaan, 6 van wie deur die Kerk benoem kon word en drie deur die Regering; die professore sou sitting mag neem in die Federale 
Raad van die Universiteit en die studente van Potchefstroom sou ook in aanmerking kan kom vir beurse waarop hulle geregtig was volgens hulle bekwaamheid. ${ }^{80}$ )

Nadat die Kuratore beraadslaag het oor hierdie belangrike informasie wat aan hulle voorgehou is deur gemelde persone, het hulle hesluit om die hele aangeleentheid deur die Sinode te laat behandel en aan te dring op die bewilliging van die advies insake 'n kommissie met volmag om te handel oor alle voorkomende voorstelle of wenke met in agneming van die voorgehoude wat vermeld is in die stuk wat as preadvies voor die Sinode gebring was. ${ }^{80} \mathrm{~A}$ )

Die Sinode het die hele aangeleentheid bespreek by die lig van die gegewens vervat in bogenoemde rapporte van die Kuratore en toe die vesoek bewillig. ${ }^{*} \mathrm{~B}$ ) In art. 166 van die Acta vind ons verder die name van die ses persone wat saam met die Kuratore en die Senaat van die Teologiese Skool aandag moes gee aan hierdie saak. Die Sinode het met hierdie besluit ook nog die volgende punte wat die Kuratore aanhangig gemak het as byvoegsel by hulle rapport, goedgekeur: Dié deel van die rapport lui soos volg: „Verder moet de ondergetekende ook nog onder uwe aandacht brengen de volgende voorstellen in verband met het Litteraries Departement van onze Theologiese School, teneinde dit Departement tot meerdere zelfstandigheid te brengen, namelik:

1) De naam van onze School zal vooralsnog zijn: „De Theologiese School (Litteraries Departement)".

2) Voor het Rektoraat zullen zowel de Litterariese als Theologiese Professoren in aanmerking moeten komen.

3) Dat er voortaan Lektoren zowel als Professoren aan dit Departement werkzaam moeten zijn." ${ }^{80} \mathrm{C}$ )

Die kommissie wat deur die Sinode van 1916 benoem is om aandag te skenk aan die saak van die Literariese Departement het vergader op 29 Nov. 1916 en na grondige oorweging van die hele aangeleentheid die volgende besluit geneem:

Deze Vergadering spreekte het als hare overtuiging uit en besluit dat geen stap genomen moet worden om medewerking van de Theologische School en 't Kollege Departement van de Gereformeerde Kerk met andere lichamen te verzekeren met 't oog op universitair onderwys, waardoor het medezeggenschap onzer Kerk, voornamelijk tot handhaving van onze beginselen, niet bewaard 
blijve. In zoodanig geval besluit zij dan liever pogingen aan te wenden en middelen te beramen waardoor zij in staat gesteld worden om te ontwikkelen tot een eigen Vrije Universiteit op Gereformeerde grondslag met of zonder sawenwerking van andere lichamen, met of zonder Staatssubsidie.

Intussen besluit $z i j$ ' $t$ schrijven te richten aan de Statuten Kommissie van de Universiteit van Zuid-Afrika om door haar bemiddeling 't beginsel van eventuele affiliatie in de statuten opgenomen te krijgen om dan later te beslissen of affiliatie op de daarin aangeboden termen mogelijk en gewenste is. Voor dit doel wordt 'n kommissie van drie leden benoemd om dit schrijven op te stellen en de gemelde statutenkommissie te ontmoeten, alsook om Dr. W. J. Viljoen, Direkteur van Onderwijs $O$. Vrijstaat, te verzoeken onze kommissie te introduceren.

Ingeval het blijkt dat op bovengenoemde wijze geen ingang voor onze School gevonden kan worden, zo besluit deze vergadering dat diezelfde kommissie zich moet wenden tot de bevoegde autoriteiten met het doel teweeg te brengen dat zij opgenomen wordt als 'n konstituerende Kollege van de Universiteit van $\mathbf{Z}$. Afrika zodat het medezeggenschap onzer Kerk „voornamelijk tot handhaving van onze beginselen bewaard blijve." ${ }^{81}$ )

Ons merk op dat in hierdie besluit sprake is van affiliasie en van inkorporasie. Wat presies onder affiliasie verstaan moet word, is nie duidelik uit die stukke nie, maar skynbaar was dit bedoel as 'n vorm van verbinding met die Universiteit van Suid-Afrika sonder egter om daarin op te gaan en sodoende die beginsels van die inrigting in gevaar te bring.

Op die volgende vergadering van genoemde sinodale kommissie, gehou op 23 Oktober 1917, is dan ook gerapporteer dat die wet van die land geen opening bied vir affiliasie nie ${ }^{82}$ ) Hiermee was die een moontlikheid dus uitgeskakel. Op hierdie vergadering het die subkommissie verder rapport gedoen oor die ander moontlikheid, nl. om die inrigting as 'n konstituerende Kollege te probeer kry. Uit die rapport blyk dat 'n onderhoud met die Minister van Onderwys, die Edele Heer F. S. Malan, plaasgevind het en dat hy aan die hand gedoen het om die Kollege Departement met 'n private wetensontwerp erkenning te laat verkry. Die kommissie het daarop 'n brief aan die Minister gerig waarin die volgende beginsels vervat is: 
a) Het Kollege zal geen ,sektariese" standpunt innemen;

b) de Regering zal vertegenwoordiging hebben op de Raad van het Kollege en

c) de kollegegebouwen en gronden zullen getransporteerd worden op de naam van de te benoemen Raad." ${ }^{83}$ )

Nadat die Minister hierop bevestigend geantwoord het, is met die wetspersone in aanraking gekom om 'n konsepwet op te stel. In aansluiting by hierdie rapport het die Rektor van die Skool, prof. dr. F. Postma, ook nog gewys op die onhoudbaarheid van die posisie van die Kollege ten gevolge van die eksamenmoeilikhede, waardeur die toekoms van die student baie bemoeilik word. ${ }^{\mathrm{s}}$ )

By die bespreking van die saak het 'n belangrike vraag na vore gekom, nl. die ,gewetensklousule”. In die notule lees ons daarvan die volgende: „Aan de orde werd gesteld de gewetensklousule van de wet en 't wetsontwerp $\mathrm{nl}$. of wij bij aanvaarding van dit wetsontwerp toelaten zullen om geen navraag te doen naar de godsdienstige overtuiging van de aan te stellen Professoren en of wij er toe overgaan zullen om ons Kollege Departement te inkorporeren bij de Universiteit van ZuidAfrika ....." 85 )

Die vergadering was in 'n uiters moeilike situasie en uit die notule blyk hoe daar geworstel is om tog 'n oplossing van die moeilikheid te vind. $\mathrm{Na}$ langdurige bespreking is besluit:

„Aangesien deze Vergadering voor 't tegenwoordige geen vrijmoedigheid heeft om tot inkorporatie te besluiten, onder de voorwaarden door de Sub-kom. (benoemd in art. 10(b) verg. 29 Nov. 1916) voorgelegd wordt besloten:

a) Om aan de Sub-kom. op te dragen veròer onderzoek in deze zaak in te stellen, en ook andere plannen te beramen in de geest van de Sinode nl. de scheijden van de Theologiese en Litterariese Departementen en behoud van onze medezeggenschap inzake onze beginselen;

b) om intussen aan de Kuratoren op te dragen zodanige maatregelen te nemen, dat de School op zulk 'n voet voortgezet worde, dat de deur voor eventuele hervatting van inkorporatie-plannen niet geslo. ten worde;

c) om aan de Kuratoren op te dragen om voorziening te maken voor 't nodige geld voor de uitvoering van dit besluit. ${ }^{86}$ ) 
Aanvullend by hierdie besluit is toe verder ook nog die volgende opdrag gegee aan die Sub-kom., wat onder punt a) genoem word: „De bestaande subkom. zal volgens nu genomen besluit alles onderzoeken, en bij 'n vergadering der Sinodale Kommissie in 1918, door hen te bepalen, 'n volledig verslag van hun onderzoek indienen en zal tijdig vóór die Vergadering hun verslag doen circuleren bij de leden van de Sinodale Kommissie." 87 )

So is alle kragte ingespan om die Kollege te behou of altans om die medeseggenskap van die Kerk te behou en die beginsels nie in gedrang te bring nie. Hierdie hardnekkige pogings kan alleen begryp word as ons in gedagte hou die groot opofferinge wat deur die oprigters en instandhouers van die Teologiese Skool gedoen is.

Die sub-komm. het sy taak buitengewoon ernstig opgevat en op die volgende vergadering van die Sinodale Kommissie rapport voorgelê. Aangesien die rapport die hele situasie so duidelik stel en die verskillende moontlikhede kort en saaklik opsom, word dit hier saaklik weergegee:

Die rappoort het uit drie dele bestaan:

A. Insake eksterne posisie van professore en studente ten opsigte van die nuwe reëlinge op die gebied van Hoër Onderwys:

1. As gevolg van 'n onderhoud van proff. Postma en Duvenage met die Statute-komm. is verkry dat die woord ,eksterne student" nie sal verskyn op die sertifikaat wat uitgereik sal word nie;

2. as gevolg van ' $n$ onderhoud wat prof. Postma met die Minister van Onderwys gehad het, is dr. J. D. du Toit benoem as lid vap die Raad van die Universiteit van Suid-Afrika;

3. in die maand Junie 1918 het proff. Postma en Duvenage 'n onderhoud gehad met die Uitvoerende Komm. van die Universiteit van Suid-Afrika en as gevolg daarvan is die volgende sake verkry:

a) Potchefstroom sal 'n Sentrum wees waar eksamens afgeneem kan word, sowel onder die ou- as onder die nuwe regulasies;

b) onse studente sal by die proefondervindelike eksamens in natuurkundige vakke die gebruik kan hê van die Transvaalse Universiteitskollege Pretoria.

Die volgende sake kon nie verkry word nie, omdat ons ,Kol- 
lege" ekstern is en dus nie deel in die voorreg van die interne kolleges nie:

a) Ons professore kan nie aangestel word as eksaminatore nie;

b) die kollegerapporte van ons studente sal nie in aanmerking geneem word wanneer hulle eksamens doen nie-die maksimum punte wat by die eksamen deur die eksterne studente behaal kan word, sal 100 wees, terwyl dit vir die interne studente 75 sal wees, die orige 25 word vir die interne studente verkry uit hulle kollegerapporte (jaarsyfers);

c) 'n eie leerkursus op te stel-daarom moet hulle maar die leerkursus van een van die interne Kolleges volg.

4. Eksamens kan nog afgelê word onder die ou Regulasies tot 1920, maar dixarna hoogs waarskynlik nie meer nie, sodat die Senaat van die Teologiese Skool wyselik sal handel as hulle vanaf die volgende jaar (dus 1919) die studente volgens die nuwe kursus laat oplei en dan nolens volens hulle eksamenposisie aksepteer. B. Insake Amalgamasie met die G.U.K. van Bloemfontein:

Met die outoriteite van die G.U.K. is samesprekings gevoer en tot 'n ooreenkoms is geraak dat die Teologiese Skool in noue verbinding sou staan met die inrigting, sonder om sy selfstandigheid prys te gee; die punte van ooreenkoms kom, saaklik weergegee, hierop neer:

a) Die Teol. Skool sal selfstandig voortbestaan met sy propedeutiese afdeling in Bloemfontein;

b) professore in diens van die Kuratore van die Gereformeerde Kerk werksaam aan die inrigting onder (a) sal lede wees van die Senaat van die G.U.K.;

c) professore tans in diens van Kuratore en werksaam aan die Kollege Departement sal benoem word deur die Raad van G.U.K. as professore van die G.U.K. met inagneming van verstreke diensjare;

d) studente sal oor en weer die kolleges van die twee inrigtings (Teol. Skool en G.U.K.) kan bywoon;

e) die Kuratore van die Teol. Skool sal jaarliks aan die G.U.K. 'n

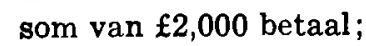

f) die Kuratore sal geregtig wees om nie minder nie as een vierde van die lede van die Raad van die G.U.K. te benoem.

Hierdie punte van ooreenkoms is reeds deur die Raad van die G.U.K. aanvaar en in 'n brief bekragtig. 
C. Insake erkenning van ons Kollege as 'n "Samestellende Kollege" deur middel van 'n private wetsontwerp.

Verskillende onderhoude is gevoer met die Minister van Onderwys en ook met die prokureur en advokat in Kaapstad en die resultaat van die samesprekinge kom hierop neer:

a) Absolute skeiding van die Teol. Skool en die Kollege;

b) naam van die Kollege sal wees „Potchefstroom Universiteits Kollege";

c) die Raad sal bestaan uit 12 lede: 4 word benoem deur die Kuratore; 4 deur oud-studente en donateurs, d.i. persone wat nie minder nie as $£ 10$ aan die Kollege sal skenk en vrywillige genootskappe (waaronder ook kerkrade e.a. verstaan word) wat

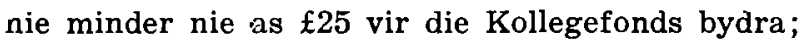

d) die "non-sektariese" klousule is weggelaat maar bly nietemin van krag kragtens die wet op die gebied van Hoër Onderwys, sodra subsidie aangevra word; kragtens 'n ander bepaling van die wet egter kan 'n nuwe professoraat of lektoraat te enige tyd deur die Raad van die Kollege daargestel word sonder die goedkeuring van die Minister, mits die koste daarvan deur die Raad self gedra word;

e) die Kuratore as Trustees van die Geref. Kerk behou die beskikking oor die fondse en eiendomme van die Teol. Skool; die Raad van die Potchefstroom Universiteitskollege sal alleen eienaar word van die fondse of gronde in sover dit deur die Trustees aan hulle toegeken en oorgemaak word;

f) volgens versekering van die Minister sal dieselfde personeel wat werksaam is aan die Kollege Departement hul benoeming ontvang as Professore aan die P.U.K. en

g) oor die verdere prosedure by die Volksraad en die koste daaraan verbonde sal inligting verskaf word. ${ }^{88}$ )

Hierdie breedvoerige rapport is bespreek en eindelik is besluit om die rapport aan die Sinode voor te lê tesame met 'n stuk wat afdeling D gemerk sal wees en wat sal handel oor die moantlikheid om 'n Vrye Universiteit te stig. ${ }^{89}$ )

Die Sinode het te Reddersburg vergader in 1918 en het voor 'n uiters moeilike taak te staan gekom om die hele aangeleentheid van die Kollege aan die hand van bogenoemde rapport en addendum te bespreek met die oog op 'n beslissing. Hoe moeilik die saak inderdaad was, veral 
waar die sgn. Gewetensklousule dan ook in die private wet opgeneem moes word, blyk uit die feit daar ses taamlike lang voorstelle op die sinodale tafel gekom het, waarvan almal nog weggeskram het van inkorporasie. Die voorstellers is toe gevra om as 'n sub-komm. te dien ten einde 'n saamvattende konsepvoorstel te kry. Hierdie sub-komm. het die volgende voorstel gebring wat ook goedgekeur is deur die Sinode: „Die Sinode het geen vrijmoedigheid om tans te besluit tot inlijwing van die Literariese Departement van die Theologiese Skool bij die Universiteit van Suid-Afrika om ernstige besware wat voortvloei uit die gewetens klausule van die Universiteitswet, wat lui als volg: ,Iemands godsdienstige gesindheid kan niet worden gesteld als voorwaarde om Professor, Lektor, Onderwijzer of Student te worden of te blijven, of om een bediening te bekleden of een emolument te gebieden, of een voorrcht in een Kollege uit te oefenen, zullende ook aan niemand die voorkeur gegeven of een voordeel onthouden worden op grond van zijn godsdienstige gezindheid'. (Sien art. 15 Hoger Onderwijswet 1917).

Die Sinode besluit diarom om 'n Kommissie te benoem, wat 'n memorie sal optrek, om namens die Sinode die Parlement te petisioneer om gemelde gewetensklousule verwyder te krij uit die wet, en hiervoor die steun ook te vra van die andere Kristelike Kerke. Voorts benoem die Sinode drie provinsiale Kommissies om die saak van die Jubileum Fonds in die verskillende Gemeentes, op uitnodiging van Kerkrade kragtig te bevorder, opdat die Fonds so hoog mogelik kan opgevoer word. Die Kommissie sal dan meteen die vermoënde lidmate vra om skenkinge aan die Theologiese Skool te doen.

Eindelik beveel die Sinode ten sterkste an die ondersteuning en uitbreiding van die reeds bestaande Vereniging vir Hoër Onderwijs op Gereformeerde grondslag, om langs die weg 'n selfstandige posiesie vir die Theologiese Skool te verseker, in oorleg met en onder goedkeuring van een toekomstige Sinode van die Gereformeerde Kerk." ${ }^{90}$ )

So was die saak van inkorporasie dan weer van die sinodetafel af en moes daar maar weer van voor af gepoog word om die weg oop te maak deur verwydering van die gewetensklousule.

Intussen moes die Kuratore en Senaat van die Teologiese Skool trag om die moeilikhede wat deur die nuwe Universiteitswet veroorsaak is te oorbrug.

Deur hierdie besluit van die Sinode is 'n hele paar sake saamgevoeg, nl. Inkorporasie, verwydering van die gewetensklousule, die Jubileum- 
fonds en die propagering van die Vereniging vir Christelik Hoër Onderwys. Die Kerk was dus besig om sy kragte te mobiliseer vir die stryd, en dit is duidelik dat die offers daarvoor gebring sou moes word.

Op die vergadering van die Kuratore gehou op 12 Feb. 1919 is besluit:

„Aan die Senaat van die Theol. School word opgedra om met die Senaat van die Universiteit van $\mathrm{Z}$. Afrika steeds in voeling te bly om die beste regelinge te tref waardeur ons studente als ,externe" onbelem. merd eksamens kan aflê." ${ }^{91}$ )

Die kommissie deur die Sinode van 1918 benoem het intussen sy opdrag uitgevoer en namens die Sinode 'n petisie voor die Parlement gelê insake verwydering van die gewetensklousule. Hierdie petisie sou egter nie dien voor die Parlement nie, want dit blyk dat, hoewel die Klerk van die Huis dit reeds goedgekeur het vir indiening, die komm. deur Ministers en parlementslede afgeraai is angesien "die parlement toe in sterwende toestand was." Dit is verder aangevoel dat aangesien 'n ander Sinodale Kommissie belas was met die opdrag om regeringssubsidie te verkry sonder prysopgawe van die beginsels, dit beter sou wees om die petisie eers agterweë te hou. Toe die nuwe Parlement verkies was, het die kommissie dadelik weer begin en op 'n voorlopige skrywe aan die Regering is die volgende telegram van die Minister ontvang: „Het spyt mij dat de Regering geen kans ziet een wetsontwerp zoals verlangd in te dienen." ${ }^{91} \mathrm{~A}$ )

Die komm. het hierop besluit om die Kuratore te adviseer om pogings in die werk te stel om die Sinode vervroeg te kry en die redes vir hierdie stap was die volgende:

„a) Om finaliteit op so'n prinsipiële punt te kry, het sy pro of kontra, sal enige jare tyd vereis, veral soos die Parlement nou saamgestel is;

b) di komm. het kennis geneem dat die toestand van die Kollege van 'ile aard is dat nie langer as vanjaar op 'n beslissing kan gewag word nie, volgens informasie aan Alg. Vergaderings verskaf. Veral neem ons in oorweging die feit, dat die studentetal met die helfte verminder is en dit terwyl alle ander Kolleges hard vooruitgaan.

Die stuk aan die Kuratore gerig lui dan verder:

„Die Komm. gee daarom die Kuratore aan die hand, onder omstandighede, dat die Sinode opgeroep word nie later as 15 September a.s. om finaal in die saak te beslis. Verder neem die Komm. die vryheid om 
op grond van informasie tot sy beskikking, die oortuiging uit te spreek, dat 'n klousule, wat reg sal gee om professore aan te stel op grond van kerklike belydenis, geen kans het om in parlementêre akte ingelyf te word nie. Ook die klousule, waarop subsidie verkry word, sal deur die Regering, blykens uitdruklike verklaring van die Minister van Onderwys, nie bestendig word nie. Sodat die saak hierop neerkom, of daar besluit word om te inkorporeer op die klousule.

Volgens die uitdruklike verklaring van die Min. van Onderwys self is die klousule daar om kerklike maar nie kristelike onderwys te weer nie.

Die Komm. is verder van oordeel, dat die reg van protes moet opgehou word, wanneer dit nodig mog bevind word. En die Komm. is verder van oordeel, dat die Kerk dit veel beter kan doen as die Kollege eers in die Raad en Senaat deur erkenning sig kan laat geld.

Eindelik moet die Komm. nog rapporteer dat na raadpleging met voormanne van ander Kerke, dit geblyk het, dat van die kant in hierdie saak geen kragtige steun te verwag is nie, aangesien ander liggame in die klousule berus met die ondervinding dat dit hulle geen moeite veroorsaak nie." ${ }^{92}$ )

Die opdrag van die Sinode van Reddersburg 1918 het dus die deputate so ver gebring dat hulle maar gevra het vir ' $n$ vervroegde Sinode, want die toestande aan die Skool was nie mooi nie, gesien die slinke van die getal studente; maar verder het hulle ingesien dat die stryd teen die gewetensklousule ' $n$ werk van jare gaan wees en dit nog sonder die kragdadige steun van die ander Kerke, wat blykbaar tevrede was met die toedrag van sake.

Dit was die ware toedrag van sake en dit was nodig dat 'n vervroegde Sinode aandag moes gee daaraan.

Die versoek van die sub-komm. is deur die Kuratore bewillig en met medewerking van die nodige instansies is die Sinode opgeroep om te vergader op Colesberg en wel op 24 Sept. 1920.

Die Kuratore het al die nodige stukke op die sinodetafel gelê en hulle spesiale rapport hieroor het die volgende stukke bevat:

A. Rapport van Sinodale Kommissie insake Gewetensklousule in Universiteitswet tesame met 'n brief van die Sekretaris van UnieOnderwys insake subsidie;

B. Rapport van die Senaat van die P.U.K. insake die Eksterne Posisie; 
C. Die Balansstaat van die Potchefstroom Universiteits Kollege (1 Apr. 1919-31 Maart 1920) Uitgawe en Inkomste;

D. Begroting van uitgawe vir die P.U.K. vir 1921. ${ }^{92} \mathrm{~A}$ )

Hieroie stukke het belangrike informasie bevat en dit is nodig dat daaroor een en ander gesê word.

A. Rapport van die Sinodale Komm.

Hierdie rapport het ons reeds vir die grootste gedeelte aangehaal by die behandeling van die versoek aan die Kuratore vir 'n vervroegde Sinode, gevolglik volstaan ons daarmee, sover dit daardie deel van hulle opdrag raak.

Wat subsidie betref het die Sekretaris van Onderwys geskrywe dat die Regering die versoek bewillig op 'n pond-vir-pond-basis tot ' $n$ bedrag van $£ 4,000$ en wel onder die volgende voorwaardes:

1) Dat het Kollege geheel zal worden afgezonderd van het Theologiese Departement volgens besluit van de Sinode en onder een zelfstandige Raad zal worden geplaatst;

2) Dat gelden wederzijds voor het Kollege bijgedragen op generlei wijze zal worden aangewend, direkt of indirekt, ten bate van gemelde Theologiese Afdeling;

3) Dat gemelde subsidie tijdelik zal zijn, voor minstens drie jaren, opdat de Raad van Kuratoren in de gelegenheid gesteld worden om de kwestie van inkorporatie volgens wet aanhangig te maken, wat eerst over drie jaar kan geschieden;

4) Bij de aanstelling van professoren en lektoren zal alleen zorg gedragen dat het kristelik karakter van het Kollege gehandhaafd wordt, zonder aanwending van een denominationale toets; bij de toelating van studenten geldt geen godsdienstige toets;

5) De H.Ed. Regering zal het recht hebben zich te laten vertegenwoordigen tot een getal van een-vierde van de lede van de KollegeRaad." 93)

Hierdie voorwaardes is vir die eerste keer gestel in 'n brief wat dr. J. D. du Toit aan die Minister gerig het en toe daarna deur die Minister aanvaar en as voorwaardes gevoeg by die subsidiebesluit van die Regering.

B. Rapport van die Senaat oor Eksterne posisie.

Die rapport van die Senaat oor hierdie saak het die posisie noukeurig geteken, en daaruit sou die Sinode kom opmaak onder watter 
moeilike omstandighede die werk verrig moes word en watter gevare gevolglik die Kollege bedreig het.

C. Balansstaat van die P.U.K.

Die staat van uitgawes en inkomste vir die tydperk van 1 Apr. 1919 - 31 Maart 1920 vermeld dat die uitgawes 'n bedrag van $\mathfrak{£ 5 , 8 5 5 , 1 0 , 0}$ beloop het en dat die inkomste die bedrag van $£ 6,152.18 .9$ behaal het, sodat 'n kredietbalans van $£ 297,8,8$ getoon kon word.

D. Die Uitgawebegroting vir 1921.

Die uitgawebegroting vir 1921 het ' $n$ bedrag vertoon van $\mathfrak{£} 7,488.2 .0$ sodat by die subsidie van $£ 4,000$ wat van regeringskant toegesê was nog bykans $\mathfrak{£ 3 , 5 0 0}$ gevind moes word.

Voor die Sinode is ook nog gelê „Die Rapport oor die Potchefstroomse Universiteitskollege vir Kristelik Hoger Onderwys vanaf September 1918-September 1920." Dit was dus 'n verslag wat oor twee jaar gestrek het en daarin was ook opgeneem die Statute van die Kollege soos deur die Kuratore vasgestel op 21 Mei 1919. ${ }^{94}$ )

In die spesiale rapport van die Kuratore aan die Sinode was bogenoemde belangrike stukke opgeneem, maar die Kuratore kon oor hierdie uiters belangrike saak nie met 'n eenparige voorstel voor die Sinode kom nie, want naas die meerderheidsvoorstel om te inkorporeer was d:aar ook 'n minderheidsvoorstel onderteken deur kurator D. Postma van Burgersdorp.

Die meerderheidsvoorstel lui soos volg:

„Met die oog op die rapport, ingedien deur die kommissie insake die gewetensklousule, en met die oog op die ander rapporte insake die Kollege-afdeling wat voorafgaan, besluit die Kuratore aan die e.k. Sinode die volgende voor te stel:

I. Dat aan Kuratore opgedra en volmag gegee word om die Kollegeafdeling by die Universiteit van Suid-Afrika te inkorporeer.

Die oorwegings wat Kuratore daartoe gelei het is die volgende:

(1) Deur die nuwe Universiteitswet is ons Kollege-afdeling as vrye stigting van Hoër Onderwys in 'n onmoontlike posiesie gekom;

(2) die finansiële laste, verbonde aan die onderwys van die wetenskappe na die eis van die tyd gaan die draagkrag van die Kerk te bowe.

Aangesien egter die Kerk groot belang het by die Kollegeafdeling, omdat die aankomende theologiese studente daarin hul voor- 
bereidende litterariese onderwys moet ontvang en aangesien hulle in voeling moet bly met die wetenskaplike ontwikkeling op alle terreine, word die Sinode geadviseer om aan die Kollege-afdeling 'n subsidie toe te ken, onderworpe aan die volgende voorwaardes:

(1) die Sinode sal van tyd tot tyd die subsidie-bedrag bepaal;

(2) op ieder sinode-sitting sal oor die rigting en gees van die Kollege gerapporteer word;

(3) die kerklike nominees wat in die Kollege Raad sal sitting hê sal kuratore wees.

II. Wat aangaan die gewetensklousule, wat nog nie verwyder is nie en waaronder ons nou noodgedwonge moet inkorporeer, adviseer die Kuratore om 'n kommissie te benoem wat sal voortgaan om gemotiveerde besware in te dien by toekomstige regerings en ook om die medewerking van ander Chris. Kerke te verkry ten einde die gewetensklousule veranderd te kry.

III. Ten einde meer verteenwoordigers onsersyds te verkry op die Kollege Raad volgens die wetsontwerp en die Kollege finansieel sterk te maak, dring die Sinode ten sterkste aan by ons kerklike en geesverwante persone om lid te word van die Vereniging vir Hoër Onderwys." 95)

Die minderheidsvoorstel het die Sinode geadviseer om nie te inkorporeer nie, maar om met Gods krag te volhard. Dit was onderteken deur ds. D. Postma van Burgersdorp en lui soos volg:

„Waar die Kerk tans, met die aanvaarding van Staatssubsidie aan ons Kollege, voor die feit geplaas word of die Kollege sal ingelyf word by die Universiteit van Suid-Afrika, en lettende op die gees van die tyd, n.l. altyd meer los van die Kerk, veral soos dit openbaar word uit die Wet op Hoër Onderwys met die gewraakte gewetensklousule, luidende . . (hier volg die artikel se bewoording) en beseffende dat dit alles beteken 'n ondermyning van ons Gereformeerde Belydenis soos uitgedruk in ons Drie Formuliere van Enigheid, adviseer die ondergetekende die Sinode om nie ons Kollege by die Universiteit van Suidafrika te inkorporeer nie, maar met Gods hulp ons selfstandigheid te bewaar deur ons Kollege te handhaaf as 'n Voorbereidende Departement vir die opleiding van ons predikante en ons studente vir sulke grade op te lei as deur ons kan behartig word. Verder word die Sinode geadviseer om voort te gaan met aksie om bogenoemde gewetensklousule uit die Wet op Hoër Onderwys verwyderd te kry, sodat ons dan met behoud van ans begin- 
sels ons Kollege kan inkorporeer by gemelde Universiteit en ons also ook 'n middel in Gods hand kan word vir die gelowige in Suidafrika die Hoër Onderwys vry te maak." ${ }^{96}$ )

Met al die gewigtige stukke op die sinodetafel moes die Sinode dus delibereer oor inkorporasie van die Kollege al dan nie.

$\mathrm{Na}$ 'n langdurige debat het die Sinode die volgende besluit geneem:

„Die Sinode bly staan by die beginsel, altyd deur die Geref. Kerk gehandhaaf, dat die onderwys in Lettere en Wetenskap en alle ander onderwys aan die ouers behoort. Maar lettende op die verslag van die Kuratore dat die Wet op Hoger Onderwijs dit op die oomblik onmoontlik maak om die beginsel in die Wet beliggaam te kry, besluit die Sinode om aan die voorstel vervat in die Meerderheids Rapport van die Kuratore te voldoen, met opdrag aan die Kuratore om met en na inkorporasie by die Universiteit van Suid-Afrika alle mogelike stappe te neem dat die tradisionele beginsels en karakter van die Skool gehandhaaf word, indien mogelik met behoud van die teenwoordige naam Potchefstroom Universiteit Kollege vir Kristelik Hoger Onderwys." ${ }^{97}$ )

Met hierdie besluit het die Sinode dus die pad van inkorporasie gekies, maar tog nie om gedwee te gaan berus in die toestand nie. Die stryd vir die beveiliging van die beginsels sou voortgeset word en is dan ook inderdaad met krag gedaan, soos die verdere geskiedenis van die Kollege behoort uit te wys.

J. P. JOOSTE.

\section{LYS VAN VERWYSINGE}

1) Handelinge van die Eerste Algemeene Synodale vergadering der Gereformeerde Kerk 1862, art. 22.

2) Handelinge van de Tweede Algemeene Synodale Kerk vergadering, Juny 1863, art. 18, bl. 10.

3) Idem

4) Handelinge, 1863, art. 23, bl. 11.

5. Idem.

6) Handelinge, 1863, art. 41, bl. 13.

7) Idem, art. 63, bl. 17.

8) Idem, art. 64, bl. 17.

9) Idem, 1869, art. 34, bl. 12.

10) Acta, 1869, art. 55, bl. 17.

11) Idem.

12) Idem, art. 56, bl. 17. 
13. Idem, art. 57, bl. 17 .

14) Gouden Jubileum Gereformeerde Kerk Burgersdorp K.P. (1860-1910), bl. 74.

14A) Acta, Sinode 1863, art. 23.

15) Gouden Jubileum, bl. 76, 77.

16) Idem, bl. 77, 78.

16A) Idem, bl. 78.

17) Idem, bl. 81.

18) Idem,bl. 81.

19) Acta van Sinode 1869 , art. 61.

20) Idem, art. 77, bl. 21.

21) Notule van de Kuratore, Nov. 1869, art. 25.

21A) Acta Sinode 1869, art. 77,, bl. 21.

22) Notule van de Kuratore, 1869 (Nov.), art. 29.

23) Idem, art. 32.

23A) Acta van Sinode van 1873, art. 72 .

24) Idem, art. 84

25) Idem, art.106.

26) Not. Kuratore, April 1876, art. 52.

27) Acta van Sinode van 1876, art. 116.

28) Idem, art. 121.

29) Idem, art. 122.

30) Idem, art. 140.

31) Idem, art. 134.

32) Acta Sinode 1876, Bylaag 2, pag. 71.

33) Idem, Bylaag no. 6, bl. 74.

34) Notule van Kuratore Mei 1878, art. 35

35) Acta van Sinode 1879, Bylaag A, bl. 70.

36) Idem, art. 27.

37) Idem, Bylaag A, bl. 70.

38) Acta van Sinode van 1882, Bylaag C, punt 8, bl. 97.

39) Idem, art. 124, bl. 50.

40) Idem, art. 131, bl. 52, 53

41) Idem, artt. 132-134, bls. 54-56

42) Idem, Bylaag C, bls. 98, 99.

43) Notule van Kuratore Mei 1883 , art. 30

44) Acta van Sinode 1885, Bylaag $E$ (a en c)

45) Notule van Kuratore Mel 1887, art. 27.

46) Acta van Sinode 1894, art. 91, bls. 32-34.

46A) Idem, art. 94, bl. 35 .

47) Idem, Bylaag C, bl. 70

48) Idem, Bylaag D, bl. 71.

49) Idem, Bylaag E, bl. 73.

49A) Idem, art. 108, bl. 39.

50) Notule van Kuratore 15 Sept. 1902, art. 2 volledige afskrif van rapport van Rektor.

51) Idem, art. 14 
52) Acta van Sinode van 1897, bls. 64-66.

53) Not. van Kuratore 11 Feb. 1903, art. 19.

54) Idem, 20 Feb. 1903 (Middelburg).

55) Acta van Sinode van 1904, bl. 90 vir rapport van die deputate.

56) Idem, bls. $88,89$.

57) Idem, Bylaag F, bl. 92.

58) Idem, Bylaag G, bl. 93.

59) Idem, art. 77, bl. 26.

60) Idem, art. 78, bl. 26.

61) Not. van Kuratore 15 Sept. 1902, art. 14.

62) Not. van Kuratore 10 Junie 1903 , art. 7.

63) Idem, art. 23.

64) Idem, 9 Des. 1903, art. 14.

65A) Not. van Kuratore 10 Feb. 1905, artt. 6, 7.

65B) Idem, 5 Des. 1905, artt. 13 en 15.

65C) Idem, 1909, artt. 10 en 12.

66) Idem, 7 Des. 1910, art. 7.

67) Idem, 6 Des. 1911, art. 27.

68) Acta van Sinode van 1913, bl. 79.

69) Idem, bl. 79.

70) Not. van Kuratore 1913, art. 4.

71) Acta van Sinode van 1913, art. 30, bl. 17.

72) Not. van Kuratore 1 Des. 1915, art. 27.

73) Idem, art. 67.

74) Not. van Kuratore 27 Nov. 1912, art. 21.

75) Acta Sinode 1913, Bylaag E, punt b, bl. 79.

76) Idem, art. 57, pag. 24.

77) Idem, art. 30 , bls. 16 en 17.

78) Not. van Kuratore 25 Nov. 1914, art. 63.

79) Acta Sinode 1916, bylagg G, bls. 84 en 85.

80) Kur. Not. 8 Maart 1916, art. 3.

$80 \mathrm{~A})$ Idem, art. 4.

80B) Acta Sinode 1916, art. 114

80C) Idem, bylaag G, bl. 85 .

81) Kur. Not. 29 Nov. 1916, art. 10.

82) Idem, 23 Okt. 1917, art. 2.

83) Idem.

84) Idem, art. 3.

85) Ibod. art. 6.

86) Ibid. artt. 11 en 12.

87) Ibld. art. 13.

88) Die oorspronklike stuk is te vinde in die Notule van die Kuratore van 22 Aug. 1918 en verder in die Acta van die Sinode te Reddersburg 1918, bl. 71vv. 
89) Hierdie stuk is opgestel deur ds. S. O. Los en ds. T. Hamersma en dit het uit 8 punte bestaan. Die oorspronklike is te vinde in die stukke onder verw. 88.

90) Acta Sinode van 1918, art. 107, bls. 39 en 40

91) Kur. Not. Feb. 1919, art. 9.

91A) Acta Sinode 1920 , bl. 12, punt 3, art. 21.

92) Acta Sinode van 1920, art. 21, bls. 12 en 13.

92A) Idem, bls. 15vv.

93) Idem, bl. 14.

94) Idem, bls. $20-25$

95) Idem, art. 30, bls. 25 en 26.

96) Vir volledige stuk sv. acta $1920, \mathrm{bl} .27$.

97) Acta Sinode 1920, bl. 31, art. 49. 